\title{
Política Nacional de Habitação
}

JOAQUIM NEVES PEREIRA

Ex-Secretário de Interior e Justiça de Goiás. Ex-Secretário de Finanças do Distrito Federal Técnico de Administração do DASP

Através do presente relato, pretendemos oferecer aos leitores desta Revista, em estilo simples e objetivo, uma síntese dos esforços que o Govêrno vem realizando com o fim de solucionar, de modo definitivo e em moldes genuinamente brasileiros, um dos problemas que mais afligem o nosso País: a crise de habitação e de serviços urbanos.

Pelo espaço de dois meses, visitamos várias repartições, mantivemos contato com diversas instituições privadas e compulsamos mais de uma centena de documentos, compreendendo leis, decretos-leis, decretos, regulamentos, regimentos, relatórios, portarias, instruções, ordens de serviço, circulares, exposições de motivos, resoluções etc.

No curso de nossas pesquisas, tivemos ocasião de observar que, mesmo entre os que trabalham no setor, nem todos possuem exata noção de conjunto do Plano Nacional de Habitação. Grande parte não conhece, pelo menos com a necessária profundidade, a estrutura, os mecanismos e os detalhes de funcionamento dêsse notável empreendimento.

Tal desconhecimento decorre, a nosso ver, não só da maneira esparsa e fragmentária com que se apresentam os vários elementos integrantes do Plano, mas também porque as publicações a êle referentes, notadamente as que o focalizam em sua configuração geral, são redigidas em linguagem técnica e, por isso mesmo, nem sempre acessíveis à compreensão do leitor comum.

Êste fato robusteceu nossa convicção de que qualquer trabalho sôbre o Plano Nacional de Habitação, que não se restrinja a determinados círculos de especialistas na matéria, deve pôr de lado as preocupações de ordem técnica para assumir o 
caráter de simples instrumento de divulgação. E outra não foi a orientação que presidiu a elaboração dêste artigo, por meio do qual esperamos proporcionar uma visão panorâmica das realizações que o Govêrno está levando a efeito no sentido de eliminar os nossos alarmantes deficits habitacionais e propiciar a cada família brasileira, em futuro não muito distante, a oportunidade de adquirir sua casa própria, onde possa viver em situação compatível com sua condição de ser humano.

É preciso ressaltar, no entanto, que o problema habitacional não é característico de nossa época, pois as origens da habitação se confundem com as próprias origens da espécie humana.

No momento em que os nossos longínquos antepassados, por fôrça da modificação das condições ambientes, perderam seu primeiro habitat, que eram as grandes florestas, adotaram a posição vertical e tiveram que viver nos descampados, sentiram a instintiva necessidade de um alojamento que os protegesse contra as intempéries e contra as agressões dos seus inimigos naturais. Passaram, então, a viver em grutas e cavernas.

Com o correr do tempo, porém, êsse tipo de abrigo mostrou que não preenchia os requisitos indispensáveis ao atendimento das exigências dos seus rudes ocupantes. Além de sombrios, úmidos e insalubres, eram fixos e não raro mal situados, o que os tornavam contra-indicados como moradia permanente de sêres cujas atividades se caracterizavam por constantes deslocamentos na busca de alimentos.

O homem primitivo viu-se, pois, obrigado a abandonar tais alojamentos e, a partir dêsse instante, teve início uma fantástica e contínua experiência que se estendeu até aos nossos dias e certamente se projetará no futuro.

Esta longa e fascinante página da história do homem sôbre o Planêta mereceria um estudo mais aprofundado, o qual, entretanto, foge inteiramente aos objetivos e aos limites do nosso trabalho. Não vamos, pois, relatar aqui como nossos ancestrais, através de milênios incontáveis, descobriram inúmeras modalidades de habitação, empregaram as mais variadas espécies de materiais em suas construções, procurando torná-las cada vez mais higiênicas, sólidas e confortáveis. O que nos interessa agora é examinarmos o problema em têrmos atuais e a importância por êle assumida nos dias que correm.

A carência de habitações e a deficiência de serviços urbanos são fenômenos de âmbito mundial que afetam não sòmente os países subdesenvolvidos ou em fase de desenvolvimento, mas 
até mesmo as nações industrializadas. Tanto naqueles quanto nestas, o processo de urbanização desordenado tem dado origem à ocorrência de problemas de natureza vária, cuja solução se torna cada vez mais intrincada, em face da complexidade do fenômeno, de suas implicações na estrutura econômico-social e, especialmente, do vulto dos recursos exigidos para o encaminhamento de soluções adequadas.

Como observa o Dr. Mário Trindade, Presidente do Banco Nacional de Habitação, "em qualquer dos casos o que mais importa e que exige cada vez mais um enfoque global e interdisciplinar na busca de soluções, é o fato de não permitir à crise urbana um relacionamento do ser humano com o meio que lhe permita o desenvolvimento de suas potencialidades para que possa usufruir uma vida plena e digna com a solução das suas necessidades básicas - alimentação, educação, saúde, trabalho, habitação e recreação".1

Embora intimamente relacionados, urbanização e desenvolvimento nem sempre caminham pari passu. $O$ ideal seria que o desenvolvimento antecedesse a urbanização, o que possibilitaria, embora com os naturais sacrifícios, a realização dos investimentos indispensáveis ao atendimento das necessidades nesse setor. Ocorre, porém, que quase sempre a urbanização precede o desenvolvimento ou mesmo quando os dois processos têm uma progressão paralela, o desenvolvimento pode estacionar, enquanto a urbanização prossegue em ritmo ascensional.

Foi o que aconteceu em algumas regiões da América Latina no início da década de 30 , quando da grande depressão econômica. Não obstante o desenvolvimento haver sofrido solução de continuidade, o processo de urbanização não se deteve, embora sua marcha fôsse menos acelerada. Também no Brasil, de 1961 a 1964, verificou-se fenômeno semelhante, pois ao passo que as atividades econômicas pràticamente entraram em recesso, as taxas de urbanização apresentaram índices bastante elevados.

Mas, "o desenvolvimento econômico é condição essencial para a organização material, técnico-administrativa e eficaz da cidade. Com efeito, a provisão de habitações higiênicas, de água potável e de conjuntos residenciais, de escolas e hospitais,

1. Dr. Mário Trindade - Conferência proferida na Escola Superior de Guerra, em 7 de julho de 1970, pág. 1. 
assim como de tôda gama de serviços só pode ser realizada em têrmos satisfatórios à medida que aumenta a renda". ${ }^{2}$

Foi exatamente por isso que o Govêrno brasileiro, ao instituir, em 1964, a Política Nacional de Habitação, procurou realizar um planejamento global, com o objetivo de transformar a ação nesse importante campo não apenas num meio de irradiação dos elevados deficits habitacionais, mas sobretudo num fator estimulante e coadjuvante do nosso crescimento econômico.

No início das atividades do Banco Nacional de Habitação, as condições do País eram sumamente precárias, o que tornava difícil a escolha de uma estratégia que pudesse conciliar os grandes investimentos na construção de habitações com a política econômico-financeira do Govêrno, cuja meta principal era o combate sem tréguas ao surto inflacionário.

Naquela época, como se recorda, a inflação entrara em franca disparada, atingindo taxas superiores a $10 \%$ ao mês; a população crescia na base de $3 \%$ ao ano; havia desemprêgo pela dificuldade de absorção da mão-de-obra em virtude da política de contenção inflacionária; e a capacidade de endividamento do País era baixa, motivo por que o recurso ao crédito externo mostrou-se desde logo sem condições de viabilidade.

0 crescimento urbano se processava com excepcional rapidez e de forma tumultuária, registrando no decênio 1950/1960 a inquietante taxa de $63 \%$. Em conseqüência da intensidade de tal fenômeno, as nossas cidades estavam sendo desfiguradas, com o aparecimento de favelas, mocambos, invasões e outros aglomerados humanos cuja situação é verdadeiramente lastimável.

O deficit habitacional brasileiro era estimado em 8 milhões de unidades e a indústria de construção civil estava virtualmente paralisada. O deficit, aliás, não era apenas quantitativo, mas também qualitativo, pois metade das habitações existentes, ou seja, 6,5 milhões, não apresentavam as desejáveis condições de habitabilidade, por falta dos serviços essenciais, como água, esgôto e instalações sanitárias.

Aos deficits qualitativos e quantitativos, juntava-se o de demanda não satisfeita, decorrente do crescimento da população na ordem de 2.200 .000 habitantes por ano, o que exigia oferta de nada menos de 440.000 unidades residenciais em cada doze meses, sem o que o equilibrio jamais seria estabelecido.

2. Tecnologia y Sociedad - La Urbanización en America Latina Publicação da UNESCO, editada por J. Thone, Liège, Bélgica, 1962, pág. 37. 
Várias causas contribuíram para agravar o problema, destacando-se entre elas a inflação que, como ninguém ignora, a partir de 1940 passou a causar sérias perturbações na economia nacional. Quem dispunha de dinheiro procurava protegê-lo contra a contínua desvalorização, aplicando-o de preferência em transações imobiliárias, de cunho especulativo, sobretudo nos grandes centros, nos quais proliferavam os loteamentos e as incorporações de edifícios de apartamentos, enquanto no resto do País permanecia a carência de habitações.

Com a excepcional valorização dos terrenos e edifícios, em conseqüência da especulação imobiliária, a classe operária foi impiedosamente excluída do processo, pois não dispunha de economias para aquisição de lotes ou construção de casa, pelos elevados preços alcançados pelos imóveis. Também a classe média inferior, com rendimento equivalente a três salários-mínimos, pelo seu modesto nível de poupança, viu-se impossibilitada de competir num mercado em que imperava a constante e violenta elevação dos preços. Por outro lado, a construção de casas para aluguel, por fôrça de uma legislação paternalista e sem apoio na realidade, teve seu ritmo sensivelmente reduzido, o que concorreu para acentuar ainda mais a escassez de moradias.

A medida que o tempo ia passando e que a desvalorização da moeda atingia índices sempre maiores, as atividades imobiliárias se retraíam, restringindo-se, quase que exclusivamente, à incorporação de edifícios urbanos, cujo preço era pago durante a construção e estava sujeito a sucessivos reajustamentos. Dessa modalidade de operações, não apenas o operariado e a classe média inferior foram afastados; também a classe média de nivel intermediário perdeu suas esperanças de adquirir casa própria, pois, a essa altura, a habitação se transformara em privilégio dos ricos ou de pessoas com renda mensal superior a dez vêzes o salário-mínimo.

Como resultado de tudo isso, desorganizou-se o mercado imobiliário e, em conseqüência, as indústrias de construção civil e de produção de materiais de construção ficaram com suas atividades reduzidas ao mínimo absolutamente indispensável à sua sobrevivência. Os custos das construções, inclusive as de tipo popular, eram muito elevados, tornando-se, inacessiveis às classes de menor poder aquisitivo.

A êsse respeito, vale transcrever na íntegra, como altamente elucidativos os seguintes trechos da "Justificação" anexa à Exposição de Motivos no 62, de 20 de maio de 1964, com a 
qual o Ministério do Trabalho e Previdência Social e o Ministro Extraordinário para o Planejamento e Coordenação Econômica submeteram à consideração do Excelentíssimo Senhor Presidente da República o projeto da reforma habitacional:

"Diante dessa conjuntura, aos setores mais necessitados de habitação restou apenas o financiamento ou a aquisição de casa pela Caixa Econômica Federal, Institutos de Aposentadoria e Pensões e Fundação da Casa Popular, no âmbito federal."

"As Caixas Econômicas só conseguem manter êste tipo de operação porque dispõem de um volume de poupanças populares que, pelo nível de educação dos seus titulares, ou pelo seu pequeno valor unitário, não procuram aplicações definidas contra a inflação. Os IAPs aplicando nestes financiamentos suas reservas técnicas contribuíram, por essa forma, para agravar sua condição de equilíbrio financeiro originada com a falta de pagamento dạs contribuições do Govêrno e muitos empregadores."

"A Fundação da Casa Popular só pode operar porque recebe anualmente recursos de natureza tributária."

"Essas entidades, para atender a seus programas, simplesmente não tomaram conhecimento da inflação. Concederam financiamento a longo e médio prazos, em prestações fixas, empréstimos àvidamente baseados, por meio de favores e pressões, não raro, em benefício de poucos privilegiados. Conseguiram, alguns, uma solução ao problema individual, à custa da renda transferida de outros setores, os quais, na realidade, pagaram a inflação. Todavia, êsse sistema revelou-se suicida no seu desenvolvimento e na sua projeção pelo tempo. Com efeito, limitados os recursos de aplicação, a reversão do capital e juros, no prazo de 20 anos, não correspondeu, feita a atualização do valor da moeda, a $30 \%$ do seu valor. A reaplicação dos meios, que asseguraria constante oferta de novos financiamentos e casas, sofreu desgaste permanente, traduzido na diferença entre o valor nominal e o real da moeda."

Os benefícios foram enormes para os compradores, que pagaram, em têrmos reais, apenas $30 \%$ do que deveriam ter pago, na hipótese de ter havido estabilização monetária. Já a instituição financiadora do imóvel adquirido, além de não haver auferido qualquer remuneração pelo capital empatado, recebeu apenas $50 \%$ do preço financiado.

"A prestação anual de amortização e juros, que no primeiro ano de contrato representava $35 \%$ do salário-mínimo vigente, 
mantida em cruzeiros nominais, ao fim do contrato representava menos do que $1 \%$ do salário-mínimo. Se essa anuidade fôsse corrigida em função da perda de poder aquisitivo da moeda, ainda assim teria sido gradualmente reduzida, como percentagem sôbre o salário-mínimo em vigor em cada ano, pois o salário-mínimo tende a aumentar em têrmos reais, isto é, em ritmo mais rápido do que a depreciação da moeda, por fôrça do desenvolvimento econômico do País."

Em face de um quadro de tal gravidade, seria absurdo esperar que quaisquer poupanças procurassem, voluntàriamente, aplicações nesse setor. $E$ as próprias instituições oficiais que atuavam em financiamentos dêsse tipo, com o passar do tempo, foram obrigadas a reduzir cada vez mais o montante de suas aplicações, pois as quantias que então recebiam, como pagamento de juros e amortização, representavam parcelas sempre menores do capital mutuado.

Os Institutos de Aposentadoria e Pensões não tardaram a encerrar virtualmente as atividades de suas carteiras imobiliárias, de vez que as grandes sangrias sofridas nesse setor vinham criando sérias dificuldades ao atendimento das necessidades fundamentais dos seus segurados relativamente ao pagamento de aposentadoria, pensões e outros encargos assistenciais.

Quanto à Fundação da Casa Popular, depois de 15 anos de experiência pouco fecunda, em que, não obstante os recursos orçamentários com que foi contemplada, construiu apenas 17.000 habitações em todo o País, pelos motivos acima apontados, acabou em completa exaustão financeira, com disponibilidades que mal chegavam para o pagamento de sua fôlha de pessoal.

Frente a uma conjuntura tão desalentadora, como a que acabamos de descrever, usando, sempre que possível, trechos e argumentos da citada Exposição de Motivos 62/64, o Govêrno não poderia continuar de braços cruzados, na posição de mero espectador. Precisava agir com presteza e energia, mas com as cautelas que a situação recomendava. A solução alvitrada aparentemente conflitava com a orientação governamental de conter a qualquer custo o processo inflacionário, como medida imprescindível ao início do saneamento das finanças.

Os fatos, porém, se encarregariam de provar exatamente o contrário.

Elaborada a estrutura geral do Plano Nacional de Habitação, teve início a institucionalização dos diversos setores e 
elementos que receberam o encargo de coordenar e supervisionar sua execução.

Segundo ressalta o Dr. Mário Trindade, em sua conferência já mencionada, a estratégia escolhida previa o planejamento físico, econômico, financeiro e social, integrados e inseridos, "progressivamente, nos programas regional e nacional. Ademais, foi realizada a integração no planejamento nacional, de modo que os investimentos nas infra-estruturas econômica e social se apóiem e se reforcem".

"Tôdas essas formas de ação, contudo, devem se constituir em sistemas flexíveis, adaptáveis às mutações que a ação provoca, de sorte que, ainda aqui, a execução e o planejamento se integrem. $O$ desdobramento da ação conseqüente provém da abertura de novos caminhos e de novas frentes, tornando-se o processo auto-excitado e auto-sustentado."

"A auto-sustentação do processo, contudo, depende de mercado, isto é, acesso permanente de novas famílias às necessidades básicas, no caso habitação e serviços urbanos. Tal se consegue com, de um lado, a redução dos custos finais da habitação; de outro, pela elevação da renda em conseqüência da ativação da economia, em escala crescente, a taxa superior à taxa de urbanização da população."

"A ampliação do mercado é, também, conseqüência da política de poupança prévia, taxa, prazos de amortização, colocando a prestação mensal para amortização da habitação numa proporção razoável da renda da família."

"Em conseqüência da estratégia exposta, é possível transformar o círculo vicioso em um verdadeiro "círculo virtuoso". Assim, a urbanização nas grandes áreas metropolitanas e nas megalópolis seria substituída pela urbanização de populações em um espectro variado, em que os diferentes tipos e tamanhos de núcleos urbanos permitam o pleno desenvolvimento da pessoa humana e o seu melhor relacionamento com os meios físico e social."

Êste é o fulcro, o ponto central e fundamental da programática do Plano Nacional de Habitação: a concentração de recursos na criação de núcleos urbanos e rurais, com facilidade de comunicação com as áreas sociais limítrofes. A constituição dos referidos núcleos, precedida de cuidadoso planejamento, além de contribuir para baixar os custos dos serviços, ainda concorre para integrar as respectivas populações no processo geral de desenvolvimento sócio-econômico, pelo acesso dos habitantes às necessidades fundamentais do ser humano, 
pelo aumento do consumo e pela maior participação do fator mão-de-obra no Produto Interno Bruto.

Considerada dêste ponto de vista, a habitação deixaria de ser um fim para constituir um meio de gerar novas rendas e de ativar tôda a economia.

Mas, como veremos oportunamente, a estratégia consubstanciada no Plano Nacional de Habitação não se exaure nos tópicos aqui transcritos. Ela é muito mais extensa e flexível, oferecendo alternativas que abrem possibilidades quase ilimitadas no que tange à construção e aquisição de casa própria.

Encarando-a de um ponto de vista mais amplo, podemos dizer que ela abrange um conjunto de elementos, atividades e investimentos que, pelas suas repercussões econômicas e sociais, constitui um dos pontos de apoio da política do Govêrno, uma vez que atende aos programas prioritários de habitação e saneamento; estimula o desenvolvimento através do aumento da taxa de investimentos; promove a saúde e o bem-estar social, não só pelo conteúdo dos programas que desenvolvem, como pela oferta de empregos que enseja; constitui forte aliado na luta contra a inflação, ao captar e investir poupanças que, de outra forma, iriam exercer pressões indesejáveis na aquisição de bens de consumo; ao aliviar pressões sôbre o orçamento da União, ajuda a reduzir as emissões para a cobertura de deficits; e, finalmente pelas razões mencionadas e por promover a reforma urbana, com o aumento permanente do número de proprietários, contribui para a maior estabilidade social e para a segurança nacional. ${ }^{3}$

Cremos que nada se deve acrescentar ao que acima ficou dito. Passaremos a examinar agora, em sua contextura e em seus detalhes, o Plano Nacional de Habitação, empreendimento que constitui verdadeiro sistema de sistemas, estruturados e administrados pelo Banco Nacional de Habitação.

Para maior clareza da exposição e para que possamos atingir o nosso principal objetivo, que é dar uma visão global de tudo que se passa no setor, agruparemos a matéria de modo que, em cada sistema, figurem todos os elementos afins ou correlatos. Dentro dessa orientação, desenvolveremos o nosso estudo de acôrdo com o seguinte esquema básico:

a) Sistema de órgão de Supervisão e Execução;

b) Sistema Financeiro de Habitação;

c) Sistema Financeiro de Saneamento;

3. Relatório do BNH relativo ao exercício de 1969 - Volume II, páginas $12 / 13$. 
d) Sistema de Captação de Recursos;

e) Sistema de Prioridades;

f) Sistema de Programas;

g) Sistema de Fundos:

h) Sistema de Projetos;

i) Sistema de Garantias;

j) Sistema de Correção das Aplicações;

I) Sistema de Apoio Técnico;

m) Conclusões.

\section{SISTEMA DE ÓRGÃOS DE SUPERVISÃO E EXECUÇÃO}

No setor público, a elaboração, execução, supervisão e coordenação do Plano Nacional de Habitação está a cargo dos seguintes órgãos e serviços:

órgãos federais

- Banco Nacional de Habitação (BNH);

- Serviço Federal de Habitação e Urbanismo (SERFHAU);

- Caixa Econômica Federal (CEF);

- Instituto de Previdência e Assistência aos Servidores do Estado (IPASE);

- Caixas Militares (CM);

- Órgãos Federais de Desenvolvimento Regional;

- Sociedades de Economia Mista.

órgãos estaduais

- Caixas Econômicas Estaduais;

- Instituições de Assistência a Servidores Estaduais;

- Companhias de Habitação.

órgãos municipais

- Companhias de Habitação;

- Instituições de Assistência a Servidores Municipais;

- Assessorias de Planejamento.

Dentro do esquema geral da política de habitação, os órgãos federais exercem de preferência atividades de orientação, coordenação, assistência técnica e financeira, ficando reservado:

a) aos Estados e Municípios, com a assistência do Govêrno Federal, a elaboração e execução de planos diretores,

4. As Caixas Econômicas Federais foram unificadas, transformando-se na Caixa Econômica Federal. 
projetos e orçamentos para a solução dos seus problemas habitacionais;

b) à iniciativa privada, a promoção e execução de projetos de construção de habitações, de acôrdo com as concepções e diretrizes urbanísticas locais.

Todo êsse complexo de órgãos, serviços e instituições, quer os de natureza governamental, quer os pertinentes ao campo da iniciativa privada, deve coordenar e harmonizar os seus esforços no sentido de concentrar os recursos disponiveis em determinadas áreas e locais, visando à consecução do máximo rendimento dos fundos investidos.

Algumas das entidades aqui referidas já integravam a nossa organização administrativa, tendo apenas passado pelas indispensáveis adaptações sem as quais não poderiam atuar em campo até certo ponto estranho às suas finalidades específicas. Duas delas, entretanto, surgiram com o advento da Lei $n$ ? 4.380 , de 21 de agôsto de 1964. Trata-se do Banco Nacional de Habitação e do Serviço Federal de Habitação e Urbanismo. Estas duas instituições, não só pela sua criação recente, mas pelo relevante papel que desempenham na formulação, execução e coordenação da Política Nacional de Habitação, serão objeto de estudo mais pormenorizado, para que se possa ter exata compreensão de como o Govêrno consegue acionar, com tanta eficiência e com tão bons resultados, a poderosa máquina que atua em todos os quadrantes do território nacional, reduzindo os deficits de moradia e proporcionando a cada família brasileira a oportunidade de concretizar um sonho a tanto tempo acalentado de poder morar em casa de sua propriedade.

BANCO NACIONAL DE HABITAÇÃO

É a peça fundamental do sistema. De acôrdo com a lei que 0 instituiu, suas funções devem limitar-se à orientação, disciplina e assistência financeira, sendo-lhe defeso operar diretamente em financiamento, compra e venda de imóveis ou construção de habitação, salvo no tocante aos terrenos que lhe forem transferidos pela União ou no caso de realização de bens recebidos como garantia.

Não obstante dispor de autorização legal para instalar agência em qualquer parte do país, para efeito de economia e para maior entrosamento com outros órgãos vinculados ao Sistema, em suas operações estatutárias o BNH deve, preferentemente, utilizar os serviços da Caixa Econômica Federal, das 
Caixas Econômicas estaduais, de bancos oficiais e de economia mista, assim como das demais entidades integrantes do Sistema Financeiro de Habitação, as quais funcionam como seus agentes ou representantes. Poderá, ainda, usar a rêde bancária particular com o mesmo fim, nas localidades em que não houver agentes ou representantes daquelas instituições.

O campo de ação do Banco é muito amplo, como se pode verificar pela enumeração das principais atribuições que lhe conferiu a Lei no 4.380/64 (arts. 17 e 18):

a) orientar, disciplinar e controlar o Sistema Financeiro de Habitação (SFH);

b) autorizar e fiscalizar o funcionamento das sociedades de crédito imobiliário, bem como disciplinar o acesso das mesmas ao mercado nacional de capitais;

c) incentivar a formação de poupanças e sua canalização para o Sistema Financeiro de Habitação;

d) financiar ou refinanciar a elaboração e execução de projetos promovidos por entidades locais de conjuntos habitacionais, obras de serviços correlatos;

e) refinanciar as operações das sociedades de crédito imobiliário;

f) financiar ou refinanciar projetos relativos a instalação e desenvolvimento da indústria de materiais de construção e pesquisas tecnológicas, necessárias à melhoria das condições habitacionais do País;

g) estabelecer as condições gerais a que deverão satisfazer as aplicações do SFH quanto a limites de risco, prazo, condições de pagamento, juros e garantias;

h) fixar os limites mínimos de diversificações de aplicações a serem observados pelas entidades integrantes do Sistema Financeiro de Habitação.

No exercício de suas atribuições, o BNH deverá obedecer os limites globais e as condições gerais fixadas pelo Conselho Monetário Nacional. Esta medida tem por fim impedir que as operações do Sistema Financeiro de Habitação, que envolvem a aplicação e movimentação de recursos em larga escala, possam divergir da orientação da política financeira, monetária e econômica do Govêrno, causando desequilíbrios e perturbações altamente prejudiciais à reabilitação financeira do País. 
Dada sua condição de banco de investimentos, o BNH não recebe depósitos diretamente do público. Poderá aceitá-los, no entanto, desde que se trate:

a) de entidades governamentais, autárquicas, paraestatais e de economia mista;

b) das entidades do Sistema Financeiro de Habitação;

c) que resultem de operações realizadas pelo Banco ou aquelas a que esteja diretamente vinculado.

Além dêstes recursos, para a realização de suas finalidades, é-lhe facultado contrair empréstimo no País ou no exterior. Todavia, suas fontes principais de suprimento, através das quais vem promovendo verdadeira revolução no setor habitacional, são o Fundo de Garantia de Tempo de Serviço, as cadernetas de poupança e as letras imobiliárias. Êstes mecanismos de alimentação do Sistema Financeiro de Habitação serão convenientemente estudados no capítulo referente ao Sistema de Captação de Recursos, no qual incluiremos também, pela sua capacidade de produzir rendas, o mercado de hipotecas.

Em outro tópico dêste trabalho, já vimos que o BNH não pode agir diretamente em financiamentos, compra, venda ou construção de habitação. Entretanto, sua esfera de atuação se estende a outras modalidades de operações, abrangendo a prestação de garantia em financiamentos obtidos no País e no exterior pelas entidades vinculadas ao SFH; a manutenção de carteiras de seguros; a manutenção de carteira de redesconto para garantir a liquidez do Sistema; o financiamento ou refinanciamento da elaboração ou execução de projetos de construção de conjuntos habitacionais, instalação e desenvolvimento da indústria de materiais de construção e pesquisas tecnológicas; o financiamento parcial dos créditos concedidos pelas sociedades de crédito imobiliário etc.

O Banco é administrado por um Colegiado (Conselho de Administração) e por uma Diretoria.

O Conselho se compõe do Presidente do Banco, que o preside, tendo apenas voto de qualidade; dos diretores, do Superintendente do Serviço Federal de Habitação e Urbanismo (SERFHAU), e de seis a nove Conselheiros, com mandato de três anos, renovável anualmente pelo têrço.

Ao Conselho de Administração, além de suas funções normativas, cabe aprovar o orçamento de custeio, recursos e aplicações do Banco; criar e extinguir cargos e funções, fixando os respectivos vencimentos, mediante proposta do Diretor-Superintendente; dirimir dúvidas quanto aos direitos, vantagens e deve- 
res dos funcionários; examinar e aprovar os balanços financeiro e patrimonial; examinar a prestação anual de contas da Diretoria, emitindo parecer a respeito.

A Diretoria é constituída do Presidente, demissível ad nutum, do Diretor-Superintendente e de dois Diretores, todos com mandato de quatro anos.

Os membros da Diretoria e três membros do Conselho de Administração são escolhidos entre cidadãos de reconhecida idoneidade moral e comprovada capacidade em assuntos econômico-financeiros. Dois outros membros do Conselho devem ser recrutados entre especialistas em saúde pública e previdência social.

SERFHAU

Por fôrça do disposto no art. 54 da Lei no 4.380/64, a antiga Fundação da Casa Popular foi transformada no Serviço Federal de Habitação e Urbanismo (SERFHAU), sob a forma de autarquia.

Depois do BNH, é o SERFHAU a entidade mais importante no Sistema Nacional de Habitação, notadamente no que tange à realização de planejamentos e à prestação de assistência técnica, pois a êle compete:

a) promover pesquisas e estudos relativos ao deficit habitacional, aspectos do planejamento físico, técnico e sócio-econômico da habitação;

b) promover, coordenar e prestar assistência técnica a programas regionais e municipais de habitação de interêsse social, os quais deverão necessàriamente ser acompanhados de programas educativos e de desenvolvimento e organização da comunidade;

c) fomentar o desenvolvimento da indústria de construção, através de pesquisas e assistência técnica, estimulando a iniciativa regional e local;

d) incentivar o aproveitamento da mão-de-obra e dos materiais característicos de cada região;

e) estimular a organização de fundações, cooperativas, mútuos e outras formas associativas em programas habitacionais, propiciando-Ihes assistência técnica;

f) incentivar a investigação tecnológica, a formação de técnicos, em qualquer nível, relacionados com a habitação e urbanismo; 
g) prestar assistência técnica aos Estados e Municípios na elaboração de planos diretores, bem como no planejamento da desapropriação, por interêsse social, de áreas urbanas adequadas a construção de conjuntos habitacionais;

h) prestar assistência técnica aos Estados, aos Municípios e às emprêsas do País para constituição, organização e implantação de entidades de caráter público, de economia mista ou privadas, que tenham por objetivo promover a execução de planos habitacionais ou financiá-los, inclusive assisti-los para se candidatarem aos empréstimos do BNH ou das sociedades de crédito imobiliário;

i) estabelecer normas técnicas para a elaboração de Planos Diretores, de acôrdo com as peculiaridades das diversas regiões do País.

\section{SISTEMA FINANCEIRO DE HABITAÇÃO}

O Sistema Financeiro de Habitação (SFH), destinado a fornecer recursos para construção e aquisição de casa própria, máxime pelas classes de menor renda, é constituído dos seguintes órgãos:

a) Banco Nacional de Habitação (BNH);

b) Caixa Econômica Federal;

c) Caixas Econômicas Estaduais;

d) Instituto de Previdência e Assistência aos Servidores do Estado (IPASE);

e) Clubes, Caixas e Associações Militares;

f) Instituições de Previdência e Assistência a Servidores Estaduais e Municipais;

g) Bancos oficiais e particulares, quando devidamente credenciados;

h) Sociedades de Crédito Imobiliário;

i) Sociedades de Crédito, Financiamento e Investimento que disponham de carteira de crédito imobiliário;

j) Associações de Poupança e Empréstimo (APE);

I) outros órgãos federais, estaduais e municipais em que haja participação majoritária do poder público e que operem no financiamento de habitações e obras correlatas. 
Examinaremos a seguir, em breves comentários, a posição das principais entidades acima mencionadas no Sistema Financeiro de Habitação.

BANCO NACIONAL DE HABITAÇAOO

É o órgão de orientação, coordenação e centralização de tôda a programação do Sistema.

Com um capital e reservas de Cr\$ 578,6 milhões de cruzeiros, ao encerrar o seu quinto exercício financeiro, em dezembro de 1969, apresentava um ativo de 4,5 bilhões de cruzeiros.

No que se refere aos programas habitacionais, o $\mathrm{BNH}$ age, ora como banco de investimento, ora como banco central do Sistema Brasileiro de Poupança e Empréstimo (SBPE).

Como banco de investimento, concede financiamento por intermédio dos diversos agentes do SFH, através de quatro programas básicos:

a) Programa de Financiamento do Mercado Rural;

b) Programa de Financiamento Popular do Mercado Urbano;

c) Programa de Financiamento Econômico do Mercado Urbano;

d) Programa de Financiamento Médio do Mercado Urbano.

Na qualidade de banco central do SBPE, compete-Ihe estimular e garantir, no campo financeiro, as operações das entidades integrantes dêsse Sistema, que são as Caixas Econômicas (federal e estaduais), as Sociedades de Crédito Imobiliário e as Associações de Poupança e Empréstimo. Neste setor, o banco atua através do Programa Habitacional de Estímulo e Garantia ao SBPE.

Há ainda os financiamentos dos programas complementares de saneamento, de materiais de construção e de apoio técnico e logístico ao Plano Nacional de Habitação e respectivos subprogramas.

De tudo isso se infere que, embora legalmente impossibilitado de operar diretamente no financiamento de construção ou aquisição de imóveis, sem a cobertura financeira do BNH e sem a sua ação coordenadora, dificilmente o Govêrno teria conseguido atingir, em tão pouco tempo, no campo habitacional, resultados tão expressivos como os até agora registrados. 
CAIXA ECONÔMICA FEDERAL

Pelo Decreto no 55.279, de 22 de dezembro de 1964, as Caixas Econômicas Federais foram adaptadas ao Sistema Financeiro de Habitação, transformando-se num dos valiosos instrumentos de ação do Govêrno no setor.

Através de acôrdos ou convênios, aquelas instituições passaram a integrar os esquemas de financiamento para aquisição ou construção de residências, com excelentes resultados, mercê da experiência que já possuiam em longos anos de operação no ramo imobiliário.

Pelos serviços que presta ao $\mathrm{BNH}$, a Caixa ${ }^{5}$ recebe uma taxa remuneratória fixada nos convênios ou contratos celebrados. Também suas agências ou sucursais podem ser utilizadas pelo Banco, como seus representantes.

CAIXAS ECONÔMICAS ESTADUAIS

A participação dessas entidades é mais ou menos semeIhante à da Caixa Econômica Federal, com as indispensáveis adaptações decorrentes da necessidade de melhor entrosamento com organismos pertencentes a outra esfera do Govêrno.

\section{INSTITUTO DE PREVIDENCIA E ASSISTENCIA DOS SERVIDORES DO ESTADO (IPASE)}

A exemplo das demais instituições congêneres, estaduais e municipais, o IPASE já possuia, à época em que foi incluído no Sistema Financeiro de Habitação, longa e preciosa experiência na construção e flnanciamento de residências para seus segurados.

É certo que seus programas de aplicação neste setor haviam sofrido deformações decorrentes do processo inflacionário e, por isso mesmo, estavam reduzidos a proporções insignificantes ou quase paralisados.

Graças à adoção do princípio da correção monetária nas operações imobiliárias, essas instituições readquiriram condições de retomar suas atividades no campo habitacional. E conseguiram fazê-lo com maior economia e eficiência, procurando atender, assim, sua numerosa clientela que é constituida, como se sabe, daqueles que prestam seus serviços ao Estado.

5. Por fôrça da unificação recentemente efetuada, existe hoje apenas a Caixa Econômica Federal. 
Para possibilitar a ampla participação dessas autarquias no Plano Habitacional, o Conselho de Administração do BNH baixou a Resolução no 96/66, pela qual o IPASE e órgãos assemelhados, além dos recursos que conseguirem angariar (contribuição dos seus associados, doações, empréstimos, etc.), ainda contam com fundos fornecidos por aquêle Banco, desde que devidamente credenciados e que apresentem programas habitacionais exequíveis. Devem, ainda, promover as necessárias alterações em suas normas de funcionamento, dando inclusive autonomia contábil e operacional a suas atividades ligadas ao setor de habitação.

Os fundos arrecadados são depositados em bancos oficiais ou na Caixa Econômica Federal e, enquanto não forem investidos na compra de terrenos, construção ou financiamento de habitações, podem ser aplicados em Obrigações Reajustáveis do Tesouro Nacional ou em. Letras Imobiliárias, para que mantenham seu poder aquisitivo.

$\mathrm{Na}$ concessão dos financiamentos, foram adotados critérios gerais e impessoais, de modo que tôdas as categorias funcionais sejam atendidas, independentemente da posição social ou política dos postulantes.

CLUBES, ASSOCIAÇÕES E CAIXAS MILITARES

As entidades em epígrafe, quando da promulgação da Lei no 4.380/64, também já eram possuidoras de grande experiência na construção e financiamento de habitações para seus associados $e$, conseqüentemente, teriam necessàriamente de ser incluídas num esquema em que se procura dar solução global ao problema da habitação no País.

A $R^{6}{ }^{6}$ ? 73/66, de 6 de julho de 1966, permitiu sua participação na construção e financiamento de residências para os elementos pertencentes aos seus quadros sociais. Os recursos, as condições e os critérios para concessão dos empréstimos são, de modo geral, os mesmos previstos para o IPASE, razão por que nos dispensamos de maiores explicações a respeito.

BANCOS OFICIAIS E PARTICULARES

Todos os bancos oficiais e particulares poderão, desde que devidamente credenciados, funcionar como agentes financeiros do $\mathrm{BNH}$, repassando recursos de diversos fundos instituídos por aquela autarquia.

6. Os atos normativos do BNH são expedidos através de RC (Resoluções do Conselho de Administração) ou RD (Resoluções da Diretoria). 
A matéria está disciplinada em numerosas resoluções dos órgãos diretores do Banco, entre as quais se destaca a RC n? $30 / 67$, que aprovou o Programa de Financiamento de Materiais de Construção (FIMACO) e respectivos Subprogramas (RECON, REGIR, REINVEST).

Cada estabelecimento bancário, no ato de sua inscrição como Agente, recebe o encargo de operar em determinado Subprograma, segundo as condições gerais estabelecidas pelo BNH.

A Lei no $4.380 / 64$, em seu art. 35 , previu a criação de instituições de crédito especializadas, sob a forma de sociedades anônimas, destinadas a propiciar amparo financeiro a operações imobiliárias relativas a incorporações, construção, venda ou aquisição de habitações. São as Sociedades de Crédito Imobiliário que integram o Sistema Financeiro Nacional, têm sua organização e funcionamento dependentes de prévia autorização do Banco Central, se nacionais, ou do Poder Executivo, se estrangeiras.

Essas sociedades desempenham, no Sistema Financeiro de Habitação, papel de importância capital, de vez que possuem capacidade de gerar recursos e atuam em várias modalidades de financiamento, tais como: a) abertura de crédito em favor de empresários para financiamento de empreendimentos relativos à construção de habitações destinadas a venda a prazo; b) abertura de crédito para construção ou aquisição de casa própria com liquidação a prazo do crédito utilizado; c) desconto mediante cessão de direito de receber a prazo o preço da construção ou venda da habitação.

Os financiamentos concedidos pelas $\mathrm{SCl}$ estão sujeitos a certas limitações. Elas não podem, por exemplo, contratar empréstimos que, em conjunto, atinjam valor acima de sua capacidade de obtenção de recursos de terceiros.

As Sociedades de Crédito, Financiamento e Investimento podem integrar o Sistema Financeiro de Habitação, bastando, para tanto, que organizem e ponham em funcionamento carteiras de crédito imobiliário. 
Pelo Decreto-Lei n? 70, de 21 de novembro de 1966, foi autorizada a constituição e funcionamento de sociedades de poupança e empréstimo (APE), que são obrigatòriamente organizadas sob a forma de sociedades civis, de âmbito regional restrito, com a finalidade de propiciar e facilitar a aquisição de casa própria a seus associados, bem como captar, incentivar e disseminar o hábito de poupança.

As APE integram o Sistema Financeiro de Habitação e possuem as seguintes características essenciais:

a) a formação de vínculo societário, para todos os efeitos legais, através de depósitos em dinheiro efetuados por pessoas físicas interessadas em delas participarem;

b) a distribuição aos associados, como dividendo, da totalidade dos lucros líquidos operacionais, uma vez deduzidas as importâncias destinadas à formação dos fundos de reserva e de emergência e à participação da administração nos resultados apurados.

Estas entidades podem conceder financiamentos diretamente aos seus associados, para construção ou aquisição de casa própria, assim como a emprêsas construtoras ou a incorporadores, para realização de empreendimentos ligados à construção ou revenda de unidades habitacionais para associados.

$\mathrm{Em}$ qualquer caso, os financiamentos são garantidos por hipoteca a favor da Associação, além de outras exigências de caráter subsidiário, que poderão ser estabelecidas visando ao retôrno dos recursos emprestados.

E ainda facultado às APE o financiamento da aquisição de imóveis com mais de 180 dias de "habite-se", desde que o respectivo proprietário concorde em receber o preço da venda por meio de crédito em conta de depósito especial, com o principal dividido em prazos fixos de 1 a 5 anos, aberta à Associação, sendo facultada a retirada do depósito antes do prazo se ficar comprovado que os recursos correspondentes serão aplicados na construção de unidades habitacionais.

COOPERATIVAS HABITACIONAIS

As Cooperativas Habitacionais vêm prestando relevantes serviços na execução do Plano Nacional de Habitação.

Organizadas de acôrdo com sua legislação específica e com as normas complementares baixadas pelo $\mathrm{BNH}$, estas ins- 
tituições propiciam a diversas camadas da população, notadamente as de renda mais modesta, a oportunidade de escolher, entre as várias modalidades de empréstimos que Ihe são oferecidas, aquela que melhor se ajuste às suas possibilidades financeiras para aquisição de casa própria.

As Cooperativas Habitacionais são organizações mutualistas, de tipo fechado, sem fins lucrativos, com número prefixado de associados, tendo como finalidade exclusiva a realização de planos habitacionais para seus cooperados, através de um sistema de poupança e amortização. Dessa forma, tais instituições operam com recursos próprios e com os oriundos de financiamentos.

\section{INSTITUTOS DE ORIENTAÇÃO ÀS COOPERATIVAS HABITACIONAIS (INOCOPS)}

A despeito de não integrarem o SFH, os INOCOPs são estudados neste capítulo em face de sua direta vinculação com as atividades das Cooperativas Habitacionais.

Estes Institutos surgiram para orientar tècnicamente as Cooperativas, quer quanto à sua organização, quer quanto à aplicação dos vultosos recursos que Ihes são confiados.

Trata-se de um tipo de sociedade civil, sem fins de lucro, voltados para os problemas habitacionais em geral, no âmbito das cooperativas, e, em especial, para aquelas que se dedicam ao financiamento de unidades residenciais para a classe operária.

Dirigidos por um Conselho de Administração, composto de um Diretor-Presidente, dois diretores e dois Conselheiros, a êsses órgãos é permitido receberem assistência financeira do BNH para sua efetiva instalação.

Pela prestação de seus serviços, os INOCOPs poderão cobrar das cooperativas assessoradas uma taxa de retribuição para cobertura dos seus custos operacionais, a qual visa garantir a qualidade e continuidade dos trabalhos oferecidos.

\section{SISTEMA FINANCEIRO DE SANEAMENTO}

O Sistema Financeiro de Saneamento (SFS) compreende um complexo de órgãos e serviços e tem como objetivo fundamental a implantação de uma política realista no campo do saneamento, mediante o fornecimento de numerário para a execução dos Subprogramas REFINAG e REFINESG, de que falaremos mais adiante. 
Para a concretização de tal política, o SFS maneja recursos provenientes do Fundo de Financiamento para o Saneamento (FISANE) e dos Fundos de Águas e Esgotos (FAE), êstes de âmbito estadual e municipal.

O Sistema tem como órgão central o Banco Nacional de Habitação e suas aplicações se processam através de dois tipos de agentes, devidamente credenciados pelo $\mathrm{BNH}$ : Agentes $\mathrm{Fi}$ nanceiros e Agentes Promotores. dades:

Como Agentes Financeiros, citam-se as seguintes enti-

a) bancos em que a União, os Estados e os Municípios sejam acionistas majoritários;

b) bancos estaduais e regionais de desenvolvimento;

c) Caixa Econômica Federal;

d) Caixas Econômicas estaduais;

e) companhias estaduais de desenvolvimento.

Funcionarão como Agentes Promotores:

a) governos estaduais e municipais;

b) órgãos regionais de desenvolvimento;

c) outras entidades ligadas ao Sistema de Saneamento.

\section{SISTEMA DE CAPTAÇÃO DE RECURSOS}

Para execução de um empreendimento das dimensões do Plano Nacional de Habitação, é claro que o Govêrno precisaria buscar, fora das fontes tradicionais (orçamentária e fiscal), os vultosos recursos financeiros a serem empregados. Recorrer ao Orçamento da União seria repetir erros anteriores, além de exercer pressões inconvenientes, de natureza inflacionária, num momento em que os responsáveis pela recuperação de nossas finanças começavam a desenvolver esfôrço vigoroso no sentido de reduzir o ritmo da inflação.

Um grupo de técnicos foi incumbido de estudar o assunto e encontrar a solução capaz de compatibilizar os grandes desembolsos do PNH com o combate ao processo inflacionário. Montou-se, então, um esquema de captação de recursos na área privada, cujos principais instrumentos serão a seguir analisados.

FUNDO DE GARANTIA DE TEMPO DE SERVIÇO (FGTS)

A Lei n? 5.107, de 13 de setembro de 1966, instituiu um engenhoso processo de geração de recursos, que recebeu a denominação de "Fundo de Garantia de Tempo de Serviço". 
De acôrdo com o estabelecido no citado diploma legal e no Decreto-lei $n^{\circ}$ 20/66, que alterou alguns dos seus dispositivos, tôdas as emprêsas sujeitas à Consolidação das Leis do Trabalho ficaram obrigadas a depositar em estabelecimento bancário, dentre os indicados pelo Banco Central, em contas vinculadas, $8 \%$ da remuneração paga no mês anterior a cada empregado que optar pelo nôvo regime, excluídas apenas as parcelas não mencionadas nos arts. 457 e 458, da CLT.

Os depósitos são feitos em nome dos empregados, exceto no caso dos não-optantes, em que as contas vinculadas são abertas em nome da emprêsa.

As contas que integram o FGTS abrangem três categorias:

a) contas-optantes, que têm como titulares os empregados que optarem pelo nôvo regime;

b) contas-emprêsas, que têm como titulares as emprêsas e que são individualizadas em relação aos empregados não-optantes;

c) conta geral, que tem como titular o $\mathrm{BNH}$, destinada ao depósito das diferenças entre o montante do FGTS e o valor correspondente à soma dos valôres das contas mencionadas nas alíneas "a" e "b".

O total dos depósitos nas contas vinculadas constitui o "Fundo de Garantia de Tempo de Serviço", que é administrado pelo Banco Nacional de Habitação, com a colaboração de um Conselho Curador.

Os recursos do Fundo são aplicados, com juros e correção monetária, diretamente pelo Banco e pelos demais órgãos integrantes do Sistema Financeiro de Habitação ou, ainda, por estabelecimentos bancários para êsse fim credenciados, como seus agentes financeiros, segundo normas fixadas pelo BNH e aprovadas pelo Banco Central.

As aplicações dos recursos do FGTS se processam de conformidade com programação prèviamente elaborada, devendo as operações respectivas preencher os seguintes requisitos: a) existência de garantia real; b) estabelecimento de cláusula de correção monetária; c) rentabilidade superior ao custo do dinheiro depositado, inclusive juros.

Não obstante as deficiências de fiscalização e o crescimento dos saques em relação aos depósitos brutos, o FGTS vem produzindo recursos de grande monta, com os quais o BNH conseguiu acelerar o ritmo de execução de seu plano habitacional. 
Já vimos que, na área do $\mathrm{BNH}$, o Fundo de Garantia de Tempo de Serviço representa a principal fonte de recursos com que conta o Govêrno para execução do Plano Nacional de Habitação. Trata-se, porém, de poupança compulsória, que alcança apenas dois setores da população, ou sejam, as classes empresariais e os empregados em organizações privadas.

Um ambicioso empreendimento, como o que estamos estudando, exige, para sua completa concretização, o emprêgo de somas verdadeiramente fabulosas. E recursos de tal monta só poderiam ser levantados com a participação de tôdas as classes da população, de vez que o Govêrno, ao iniciar-se a reforma habitacional, repeliu desde logo a possibilidade da utilização de contribuições de natureza fiscal ou orçamentária.

Ao lado do FGTS, outro mecanismo bastante simples, mas de extraordinária eficácia, foi concebido e pôsto em prática. Referimo-nos às "Cadernetas de Poupança", por meio das quais a Caixa Econômica Federal, as Sociedades de Crédito Imobiliário, as Associações de Poupança e Empréstimo (APE) e as Sociedades de Crédito, Financiamento e Investimento, que operam carteiras imobiliárias, vêm canalizando para o Sistema Financeiro de Habitação recursos financeiros em grandes quantidades.

O processo se reveste de extrema simplicidade. Qualquer cidadão que disponha de superavit em seu orçamento familiar comparece a uma das entidades acima referidas e, em poucos minutos, consegue abrir sua conta de poupança, recebendo como comprovante a respectiva caderneta. As contas, quanto aos aspectos formais, são mais ou menos iguais às que comumente são abertas nos estabelecimentos bancários; na essência, porém, há diferenças fundamentais, de vez que os depósitos de poupança passam a render, conforme o caso, dividendos, juros e correção monetária.

Graças a essa modalidade de depósito, o Govêrno conseguiu atrair economias dispersas, de poupadores não tradicionais, que em conjunto atingem quantias muito elevadas.

LETRAS IMOBILIARIAS

Na conformidade do estatuído no art. 44 da Lei no 4.380/64, - Banco Nacional de Habitação, as Sociedades de Crédito Imobiliário e as Sociedades de Crédito, Financiamento e Investi- 
mento, que mantenham carteiras imobiliárias, poderão colocar no mercado de capitais letras imobiliárias de sua emissão.

As letras imobiliárias representam outra forma de captação de recursos para o financiamento da construção ou aquisição de casa própria.

Dois são os principais tipos dêsses títulos de crédito:

a) letras tipo " $C$ " ou de Renda, emitidas com o prazo mínimo de três anos e máximo de dez, e com valôres nominais de $50,100,200,500,1.000$ e 5.000 cruzeiros. São pagas ao portador à data do respectivo vencimento;

b) letras tipo " $D$ " ou de poupança, emitidas com prazo nunca inferior a um ano e com valôres nominais de 5 , $10,20,50$ e 100 UPC. $^{7}$

As Letras Imobiliárias podem ser ao portador ou nominativas. A transferência das primeiras se faz por simples tradição, a exemplo do que ocorre com as ações ao portador. Quanto às nominativas, exige-se a averbação do nome do adquirente no Livro de Registro e no próprio certificado ou, ainda, mediante o endôsso em prêto no título, datado e assinado pelo endossante.

As Letras Imobiliárias rendem juros de $8 \%$ ao ano e correção monetária idêntica à fixada para as Obrigações Reajustáveis do Tesouro Nacional. A opção por um ou por outro tipo é que define a diferença na percepção dos rendimentos.

Num como no outro tipo, os juros e a correção monetária são abonados trimestralmente. Nas do tipo "C", no entanto, o adquirente pode receber o rendimento no fim de cada trimestre. Já nas do tipo "D" ou de poupança, os benefícios se acumulam de tal maneira que se tem um valor capitalizado, pago no vencimento da letra.

As letras imobiliárias são ativos financeiros de grande rentabilidade e segurança. Para se ter uma idéia da aceitação dêsses títulos, nas diversas alternativas de investimento, basta dizer que as letras de poupança (tipo "D"), em 1969, apresentaram rendimento superior a $27 \%$.

Pelas características acima enumeradas, as Letras Imobiliárias têm larga acolhida junto ao público investidor, gerando consideráveis recursos para o Sistema Financeiro de Habitação.

7. UPC é a sigla de Unidade Padrão do Capital do BNH. Seu valor é fixado de acôrdo com o preço reajustado trimestralmente das Obrigações Reajustáveis do Tesouro Nacional (ORTN). Em julho do corrente ano, o valor de cada UPC correspondia a Cr\$ 44,67. 
O mercado de hipotecas foi instituído com a finalidade de produzir recursos para o atendimento dos seguintes objetivos: a) estimular a construção de novas habitações em áreas onde se faça necessário pelo insatisfatório desenvolvimento de outros meios de captação de recursos; b) reativar a indústria de construção civil e aumentar os níveis de emprêgo locais; c) aplicar disponibilidades não comprometidas em outros programas; d) servir como instrumento regulador e reserva de liquidez do mercado.

Pela Resolução no 101/66, do Conselho de Administração do $\mathrm{BNH}$, ficou aquela autarquia autorizada a adquirir ou prometer adquirir, nos mercados locais, créditos hipotecários corrigidos e assegurados, observadas as normas disciplinadoras da espécie.

Para o desempenho de mais esta incumbência, o BNH ficou autorizado a credenciar Agentes e Iniciadores, em todo o território nacional. Podem exercer as funções de Agentes a Caixa Econômica Federal, as Sociedades de Crédito Imobiliário e as Associações de Poupança e Empréstimo; como Iniciadores, com exceção do próprio banco, podem operar quaisquer pessoas físicas ou jurídicas, integrantes ou não do Sistema Financeiro de Habitação, titulares iniciais dos créditos a serem negociados.

Para fins de aquisição de hipotecas, os programas e projetos serão selecionados pela seguinte ordem de preferência:

a) inversões compensatórias da falta de atividade de outros órgãos locais do SFH;

b) inversões para ativação local da economia;

c) inversões para equilibrio do mercado local de hipotecas;

d) aplicações do FGTS, quando não utilizadas as disponibilidades em outros projetos;

e) inversões onde houver órgão de planejamento local integrado.

Fixou-se em 730 UPC o valor médio dos imóveis objeto de hipoteca. Os prazos para liquidação foram estipulados em 5,6 , $8,10,12,15,18$ e 20 anos, e os juros em $10 \%$ ao ano. Procurou-se, dessa forma, compatibilizar a prestação mensal com a renda média das classes a que se destinem as residências. 


\section{OUTRAS FORMAS DE CAPTAÇAO DE RECURSOS}

Além das fontes anteriormente estudadas, o Sistema Financeiro de Habitação conta, ainda, com os seguintes instrumentos da captação de recursos para suas aplicações:

a) empréstimos externos e internos;

b) depósitos de entidades governamentais, autárquicas e paraestatais;

c) repasse dos diversos fundos;

d) retôrno das quantias emprestadas, acrescidas de juros e correção monetária;

e) taxa de administração do FGTS, taxas de administração e de assistência técnica;

f) recursos oriundos das Cooperativas Habitacionais (Poupança dos cooperados);

g) recursos próprios de várias instituições autorizadas a operar no SFH (Caixas, Clubes e Associações militares, IPASE etc.);

h) recursos particulares de pessoas filiadas a essas instituições;

i) depósitos a prazo fixo e depósitos diversos;

j) doações, contribuições e subvenções de qualquer natureza.

\section{SISTEMA DE PRIORIDADES}

Num país de dimensões continentais como o nosso, com uma taxa de crescimento demográfico das mais elevadas, com regiões inteiramente diversificadas quanto ao desenvolvimento econômico e com enormes deficits de moradias, os responsáveis pelo planejamento da reforma habitacional teriam que estabelecer rigorosa escala de prioridades para os investimentos, objetivando evitar a dispersão de esforços e recursos, bem como assegurar sua utilização em áreas e programas de relevante interêsse social.

$\mathrm{Na}$ elaboração do Plano Nacional de Habitação, êstes aspectos foram devidamente considerados. Assim é que a Lei n? 4.380/64, em seu art. 4\%, condicionou a concessão de empréstimos, para construção ou aquisição de casa própria, à fiel observância das seguintes prioridades:

a) conjuntos habitacionais destinados à eliminação de favelas, mocambos, invasões e outros aglomerados com condições sub-humanas de habitabilidade; 
b) projetos de cooperativas e outras entidades associativas;

c) projetos de governos estaduais e municipais, que já disponham de áreas urbanizadas, possibilitando o imediato início das obras;

d) projetos da iniciativa privada que contribuam para a rápida e efetiva solução do problema habitacional;

๑) projeto de construção de abrigos para as populações rurais.

Pelo exame da lista de prioridades, verifica-se que mais uma vez o Govêrno basilou sua conduta por critérios gerais e de cunho eminentemente social, por isso que, sem frustrar as aspirações dos que possuem meios de pleitear e obter financiamento para construção ou aquisição de casa própria, procurou concentrar recursos em projetos capazes de produzir maior rendimento no que se refere ao atendimento das classes menos favorecidas.

SISTEMA DE PROGRAMAS

\section{I - PROGRAMAS HABITACIONAIS}

Embora predomine, no planejamento habitacional, a orientação de se estabelecer tratamento preferencial para as classes de menor renda e, portanto, as mais carentes de assistência oficial, diversas alternativas são também oferecidas a outras camadas da população, para que cada qual escolha aquela que Ihe possibilite adquirir ou construir sua casa própria. Apenas as condições não são as mesmas para todos, pois ao passo que para os mais necessitados os prazos são maiores, os juros, menores e os financiamentos, integrais, à medida que crescem as rendas dos pretendentes, os prazos diminuem, os juros aumentam e os financiamentos vão se tornando mais reduzidos, exigindo suplementação à conta da poupança dos interessados.

Dentro dessas diretrizes, os programas habitacionais foram divididos bàsicamente em mercado rural e mercado urbano, êste subdividido em três faixas, de acôrdo com os valôres unitários dos empréstimos e tendo em vista a renda familiar mínima considerada necessária.

Como partes integrantes e complementares da programação habitacional, temos o Programa de Estímulo e Garantia do Sistema Brasileiro de Poupança e Empréstimo (SBPE) e o Subprograma RECON. 
Analisaremos a seguir, através de breves comentários e do resumo de tópicos do Relatório do $\mathrm{BNH}$ referente ao exercício de 1969, os diversos programas habitacionais estruturados e executados pelo citado Banco, com a cooperação financeira das demais entidades competentes do Sistema.

\section{a) PROGRAMA DE FINANCIAMENTO DO MERCADO RURAL}

A elaboração e implantação dêste Programa, assim como a avaliação dos seus resultados apresentam sérias dificuldades, uma vez que, além de totalmente despreparadas para receberem os benefícios proporcionados pelo Govêrno, as pessoas por êle atingidas se acham espalhadas por áreas de considerável extensão, o que constitui obstáculo à distribuição dos financiamentos projetados.

Ademais, a garantia dos empréstimos via de regra não pode ser oferecida pelos beneficiários finais dos investimentos, tendo em vista que, na esmagadora maioria dos casos, são êles simples posseiros ou arrendatários das terras que ocupam. Também no tocante à correção monetária, os responsáveis pelo Plano Nacional de Habitação terão que procurar uma solução aplicável, aos financiamentos rurais, pois, como se sabe, o crescimento da renda no setor primário não tem acompanhado a evolução dos índices de preços por atacado.

Entre as medidas que as autoridades vêm estudando, com - objetivo de dar justa solução ao problema e levar a urbanização ao homem do campo, abrindo novas perspectivas de desenvolvimento econômico, inclui-se o incentivo ao financiamento de agrovilas, com a participação de outros órgãos governamentais. Esta solução ensejaria a eliminação de algumas das dificuldades até agora encontradas, pois a correção monetária incidiria apenas sôbre uma parcela do empréstimo, devendo a outra parte, oriunda de recursos fornecidos por órgãos oficiais não ligados ao plano habitacional, ficar livre dêsse ônus que sobrecarrega de forma insuportável o orçamento das familias de baixa renda.

O valor unitário dos empréstimos previstos no programa em estudo foi fixado em 150 UPC. Esta quantia, à primeira vista, parece pouco expressiva, mas na realidade não o é, uma vez que êsse tipo de habitação é construído com materiais obtidos no próprio local e com a participação dos interessados.

Apesar de o Programa de Financiamento do Mercado Rural ainda não haver sido integralmente regulamentado, já se acha 
em execução uma experiência-pilôto, através de contrato de empréstimo com o Banco do Estado do Rio Grande do Sul, com a finalidade de promover o refinanciamento de 700 unidades habitacionais e obras de instalação sanitária e acréscimo em pelo menos 1.300 habitações rurais, com um investimento global da ordem de dez milhões de cruzeiros, $86 \%$ dos quais serão cobertos por financiamentos do Banco Nacional de $\mathrm{Ha}-$ bitação.

Para o triênio $1970 / 1972$, o BNH aplicará no Financiamento do Mercado Rural a importância de 2,5 milhões de UPC.

b) FINANCIAMENTO POPULAR DO MERCADO URBANO

Através dêste programa, será financiada a aquisição de casa própria para famílias com renda igual ou superior a um salário-mínimo regional. Os empréstimos no setor são limitados ao máximo de 200 UPC.

Nesta faixa se concentram os que vivem em habitações precárias, em condições sub-humanas, e para quem os financiamentos do BNH constituem o único meio de obtenção de uma casa confortável, especialmente no que se refere à higiene e à ausência de promiscuidade.

Para êste grupo, o Govêrno procurou estabelecer maiores facilidades para aquisição de unidades residenciais. Os prazos de amortização dos empréstimos foram consideràvelmente dilatados (240 meses), os juros variam de 4,5 a $6 \%$ ao ano, de acôrdo com o montante do empréstimo, e os financiamentos dos mutuários finais serão de $100 \%$ do valor do imóvel, estimado em 187 UPC, contribuindo o BNH com $83 \%$ dos recursos, ficando o restante a cargo dos Agentes.

No triênio de 1970/1972, o citado Banco deverá aplicar neste programa quantia equivalente a 24,9 milhões de UPC, ou seja $22 \%$ do total previsto para os programas habitacionais. Se tudo correr de acôrdo com o planejamento elaborado, até 1972 serão construídas 162.000 unidades residenciais, número que, embora bastante eloqüente, representa sòmente $29 \%$ da demanda nesta modalidade de mercado.

\section{c) FINANCIAMENTO ECONÔMICO DO MERCADO URBANO}

O objetivo dêste programa é financiar a aquisição de casas destinadas a famílias com renda mensal de pelo menos 6,20 UPC e que tenham possibilidades de contrair empréstimos cujos valôres se situem entre 200 e 400 UPC. 
As aplicações neste programa, no período de 1970 a 1972, estão orçadas em 51 milhões de UPC, quantia correspondente a $45 \%$ do total dos recursos destinados ao setor habitacional. Este percentual elevado se justifica pelo fato de se concentrar nesta faixa a maior demanda de habitação.

Por se tratar de classe de renda superior à auferida pelos beneficiários do Mercado Popular, os juros variam de 7 a $10 \%$ ao ano, de acôrdo com o valor do empréstimo, e os prazos de amortização foram reduzidos para 20, 18 e 15 anos.

O número de unidades residenciais a serem financiadas no triênio deve elevar-se a 172.000 , ao preço médio de 296 UPC. A participação do BNH no programa está fixada em tôrno de $75 \%$ dos financiamentos previstos.

\section{d) FINANCIAMENTO MÉDIO DO MERCADO URBANO}

$\mathrm{Na}$ execução do programa em epígrafe, o Govêrno procurará atender às famílias com renda mensal a partir de 19,20 UPC e que tenham condições de obter empréstimos entre 400 e 720 UPC.

As aplicações neste programa, avaliadas em 10 milhões de UPC, correspondem sòmente a $9 \%$ do total das disponibilidades do BNH para o setor de habitação. Explica esta reduzida percentagem o fato de se tratar de investimentos cujos beneficiários dispõem de maior capacidade financeira e, portanto, de melhores possibilidades de adquirir casa própria mediante a utilização de outras fontes de financiamento.

Como o valor médio das unidades dêste plano deve ser de aproximadamente 475 UPC, prevê-se que as unidades financiadas atingirão o total de 21.000 .

Os juros pagos pelos mutuários finais são fixos, isto é, $10 \%$ ao ano, variando apenas os prazos de amortização que foram estipulados em 12, 10 e 8 anos, conforme a faixa de financiamento.

e) PROGRAMA DE GARANTIA E ESTIMULO AO SBPE

Êste programa opera numa área que abrange grandes contingentes da população dotados de maior poder aquisitivo.

Para o triênio 1970/1972, as previsões orçamentárias do Sistema Financeiro de Habitação consignam recursos superiores a 123 milhões de UPC, destinados a financiar a construção e aquisição de casa própria para as familias compreen- 
didas nesta faixa. O valor médio dos financiamentos é de 586 UPC. Durante a execução do programa, no triênio acima mencionado, calcula-se que serão construídas 211.000 unidades residenciais.

f) SUBPROGRAMA RECON

O subprograma RECON, cuja finalidade precipua é a interiorização do crédito para compra de materiais de construção, será estudado com minúcias no capítulo relativo ao Programa de Financiamento de Materiais de Construção (FIMACO).

g) OUTRAS POSSIBILIDADES DE AQUISIÇÃO OU CONSTRUÇÃO DE CASA PRÓPRIA

Além dos programas que acabamos de passar em revista, outras facilidades são propiciadas aos que não dispõem de casa própria, dentre as quais citaremos as seguintes:

a) construção de edifícios de apartamentos em condomínio;

b) construção de vilas e conjuntos residenciais em condomínio, por particulares;

c) construção de residências através de cooperativas das diversas categorias profissionais;

d) construção de residências para servidores públicos, pelo IPASE e instituições congêneres (estaduais e municipais);

e) construção de casas pelas Caixas, Clubes e Associações militares;

f) aquisição de moradias com menos de 180 dias de "habite-se";

g) aquisição, pelos respectivos locatários, de unidades residenciais com mais de 180 dias de "habite-se".

\section{II - PROGRAMA DE FINANCIAMENTO PARA SANEAMENTO (FINANSA)}

Problema da mais alta gravidade, dada sua importância para a saúde e bem-estar das populações, é o que diz respeito à deficiência de serviços essenciais (água, esgôto e instalações sanitárias) até mesmo em centros de relativa densidade demográfica, razão por que vem recebendo das autoridades habitacionais tratamento prioritário. 
Segundo consta do Relatório do BNH relativo ao exercício de 1969, a partir de 1968 foram introduzidas importantes modificações no campo do saneamento, com a adoção de "uma política realista, objetiva, dinâmica e de caráter permanente". A nova orientação "assenta-se de forma segura em uma conjugação de esforços no campo financeiro, através de fundos de financiamento de água e esgotos, regionais e estaduais, que permitam garantir a solução do problema no presente e no futuro."

A política atualmente posta em prática, "constituindo um todo harmonioso, de atuação técnica, econômica e financeira, consolidada no Sistema Financeiro de Saneamento, teve em 1969 desenvolvimento satisfatório, dentro das características de realismo e objetividade que são seu traço marcante, ultrapassando-se, dessa forma, a fase inicial de implantação do Sistema".

O êxito até agora conseguido decorre, em grande parte, da maneira com que os planos foram estruturados e das diretrizes que presidem sua execução, as quais têm como objetivos fundamentais; a) auto-sustentação do processo; b) estabelecimento de suporte financeiro adequado; c) adoção de fator multiplicador dos recursos aplicáveis; d) ampla descentralização; e) entrosamento e colaboração dos diversos órgãos ligados ao Sistema; f) completa flexibilidade de funcionamento.

O Programa de Financiamento para Saneamento (FINANSA) aplicará, no próximo triênio, a quantia de 44 milhões de UPC, oriunda de fontes não orçamentárias. As atividades do Programa são distribuídas pelos seguintes Subprogramas: a) Refinanciamento de Sistemas de Abastecimento de Água (REFINAG); b) Refinanciamento para Instalação ou Melhoria de Sistemas de Esgotos (REFINESG); c) Estímulo ao Sistema Financeiro de Saneamento (EFISAN); d) Financiamento de Infra-estrutura de Conjuntos Habitacionais.

a) REFINAG

Pela RD n: 10/68, a Diretoria do Banco Nacional de Habitação aprovou o Subprograma de Financiamento ou Refinanciamento da implantação, ampliação e melhoria dos sistemas de abastecimento de água (REFINAG).

De acôrdo com o contido nas instruções reguladoras das aplicações dêste Subprograma, os financiamentos são concedidos pelo BNH, como órgão gestor do Fundo de Financiamento para o Saneamento (FISANE), e administrados pelo Superintendente do referido Fundo. 
$\mathrm{Na}$ concessão dos financiamentos e refinanciamentos, serão observadas as condições básicas estabelecidas para o FISANE, dando-se prioridade às propostas que: a) se refiram a comunidades onde os problemas de saúde decorrem do mau funcionamento dos sistemas de abastecimento de água; b) tratem de projetos considerados prioritários e incluídos em planos de aplicação propostos por organismos estaduais ou regionais; c) apresentem maior contribuição de recursos locais (municipais, estaduais ou regionais); d) assegurem a inclusão dos retornos de recursos regionais e estaduais na formação de fundos destinados ao financiamento de outros projetos do programa; e) apresentem maior rendimento social e menor prazo de amortização; f) se destinem a comunidades que tenham seu desenvolvimento orientado por "Planos de Desenvolvimento Local Integrado"; g) atendam aos programas de abastecimento de água dos conjuntos habitacionais.

Dentro de suas atribuições específicas, o REFINAG vem desenvolvendo programas de financiamento de serviços de água em todo o território nacional, contemplando cidades que antes desconheciam êsse benefício ou melhorando as condições operacionais dos sistemas existentes, "de modo a elevar o atendimento das populações a um nivel adequado ao crescimento dêsses núcleos, permitindo, também, daí por diante, a manutenção do nível de atendimento".

b) REFINESG

Instituído em 1969, com a finalidade de financiar a instalação, reforma e ampliação de sistemas de esgotos, bem como promover o contrôle da poluição das águas, o Subprograma de Financiamento e Refinanciamento de Sistemas de Esgotos (REFINESG), não obstante ainda achar-se em fase de implantação, já deu início à execução dos seus esquemas de trabalho, cujas previsões, para o próximo triênio, abrangem a realização de obras e serviços com capacidade para atender 7.000.000 de habitantes.

c) EFISAN

O Subprograma de Estímulo ao Sistema Financeiro de Saneamento (EFISAN) tem importante papel a desempenhar no contexto do Plano Nacional de Habitação.

Trata-se de iniciativa de grande alcance social e que se transformará, por certo, em poderoso instrumento de ampliação dos recursos necessários aos investimentos no setor. 
Êste Subprograma deverá atuar como elemento de apoio, cabendo-lhe incrementar a formação e a integralização de Fundos de Água e Esgotos nos Estados de baixa receita tributária "per capita", bem como incentivar e facilitar a participação de municípios de pequena renda nos fundos criados.

Dois Estados já foram favorecidos com financiamentos feitos pelo EFISAN. A Bahia recebeu 14,3 milhões de cruzeiros e Mato Grosso, 3,1 milhões.

d) FINANCIAMENTO DE INFRA-ESTRUTURA DE CONJUNTOS HABITACIONAIS

Ninguém ignora que, nos Estados e Municípios, compete aos órgãos locais específicos a execução das obras de infraestrutura no perímetro urbano, inclusive nos conjuntos habitacionais financiados pelo Banco Nacional de Habitação. Acontece que êsses órgãos, além de lutarem com a escassez de recursos financeiros, quase sempre se acham assoberbados com a realização de serviços destinados a sanar as deficiências nas áreas já construídas, ficando assim impossibilitados de arcar com esta responsabilidade adicional.

Deixar a concretização de obras dessa natureza a cargo das repartições locais seria procrastinar a entrega dos conjuntos, com sérios prejuízos para os programas estabelecidos e para os futuros ocupantes das habitações. Por outro lado, seria injusto e inaceitável transferir para os compradores - pessoas geralmente de reduzida capacidade financeira - as despesas com o financiamento dêsses serviços, impondo-Ihes um ônus para cujo atendimento não se acham capacitados.

Diante de tal situação, e considerando que, na execução do Plano Nacional de Habitação, deve haver perfeita conjugação de esforços e recursos entre os órgãos federais e os estaduais e municipais, visando a dar solução satisfatória aos problemas de interêsse comum, o BNH resolveu conceder financiamento, através das Companhias de Habitação, para o custeio de obras de infra-estrutura nos conjuntos residenciais construídos por aquelas entidades.

Os empréstimos têm caráter excepcional e podem ser repassados pelas citadas companhias, assim como por instituições federais, estaduais e municipais com atuação no local de execução dos projetos. O escopo de tais financiamentos - é bom que se repita - é permitir a instalação de serviços de água, esgôto etc., nos citados conjuntos, proporcionando-lhes condições de habitabilidade sem as quais suas finalidades sociais não seriam plenamente cumpridas. 
O repasse dos financiamentos beneficiam exclusivamente as obras dentro dos conjuntos. Na hipótese de serviços externos, tais como adutoras, afluentes sanitários, estações de tratamento e outros, os projetos devem ser apresentados, separadamente, para os devidos estudos e para o exame da possibilidade do deferimento de cada caso.

Os empréstimos são efetuados por meio de convênio entre - BNH e as COHABs interessadas, nos quais são estatuídas as obrigações das partes contratantes, relativamente à aplicação dos recursos transferidos ou repassados, à amortização, juros, garantias etc.

\section{III - PROGRAMA DE FINANCIAMENTO DE MATERIAIS DE CONSTRUÇÃO (FIMACO)}

Pela RC n $30 / 67$, o Conselho de Administração do BNH aprovou o Programa de Financiamento de Materiais de Construção (FIMACO), a ser executado através dos seguintes Subprogramas:

a) financiamento ou refinanciamento do consumidor de materiais de construção (RECON);

b) financiamento ou refinanciamento do capital de giro do produtor de materiais de construção (REGIR);

c) financiamento ou refinanciamento do investimento no ativo fixo das emprêsas produtoras e distribuidoras de materiais de construção (REINVEST);

d) financiamento de "underwriting" de aumento de capital de emprêsas produtoras e consumidoras de materiais de construção;

e) financiamento de projetos e de assistência técnica para as emprêsas produtoras e distribuidoras de materiais de construção, ou, ainda, para entidades públicas ou privadas cujos propósitos sejam a pesquisa ou a normação de iniciativas tendentes a reduzir os custos dos materiais de construção (REPART).

No ato que instituiu o FIMACO, o Conselho de Administração do $\mathrm{BNH}$ apresentou as seguintes razões justificativas da medida adotada, tendo em vista a conveniência:

a) da aceleração das obras destinadas a habitações em geral, utilizando se possivel pré-investimentos, antecipando o benefício social e promovendo o rápido aumento da oferta com vista à redução dos preços de venda e do aluguel das residências; 
b) da redução dos custos da construção decorrentes da adoção de ritmo mais econômico e pelos prováveis descontos nas compras de materiais que resultarão do pagamento à vista e do maior poder de barganha dos produtores;

c) da própria reativação do setor de materiais de construção pelo aumento e antecipação das compras, interessando, imediatamente, os produtores no aumento $e$ ampliação da oferta, condição indispensável para execução dos demais programas do Plano Nacional de Habitação;

d) da ampliação, racionalização e modernização das emprêsas produtoras, transportadoras e distribuidoras de materiais para construção, permitindo o aumento da oferta e conseqüente redução dos preços;

e) da difusão do programa a todos os pontos do País, inclusive nas pequenas cidades do interior;

f) da devolução imediata de parte dos recursos captados ao local de origem e ao setor privado, reduzindo possíveis efeitos negativos de natureza recessiva e de descapitalizadora, resultante da transferência de depósitos do FGTS.

Ainda na conformidade do disposto na mencionada RC n: 30/67, as operações do Programa e respectivos Subprogramas (RECON, REGIR, REINVEST etc.) se processam de acôrdo com os seguintes princípios básicos: descentralização das operações através de grande número de agentes e com a indispensável distribuição geográfica; utilização de processos simples, funcionais e rápidos, deferindo-se aos agentes, sempre que possível e aconselhável, o exame técnico dos pedidos de empréstimo; cobrança de taxas e juros reduzidos, compatibilizando-os com os objetivos que a operação visa a atingir; adoção de flexibilidade na distribuição dos recursos de modo que permita 0 atendimento, na devida oportunidade, de situações locais específicas.

Os recursos do Fundo são repassados por uma rêde de instituições financeiras, figurando como agentes especiais o Banco do Brasil e o Banco Nacional do Desenvolvimento Econômico, $e$, com agentes comuns, tôdas as entidades integrantes do $\mathrm{SFH}$, bancos oficiais e regionais de desenvolvimento, bancos de investimento, companhias estaduais de desenvolvimento, sociedades de crédito, financiamento e investimento, além dos bancos comerciais. 
Feitas estas breves considerações sôbre a estrutura, as finalidades e o funcionamento do FIMACO, passaremos a analisar os principais Subprogramas que o integram, assim como os resultados obtidos através dêsses valiosos mecanismos do Plano Nacional de Habitação.

\section{a) FINANCIAMENTO E REFINANCIAMENTO DO CONSUMIDOR} DE MATERIAIS DE CONSTRUÇÃO (RECON)

Este Subprograma visa a difundir e interiorizar o crédito destinado à aquisição de materiais de construção.

Os financiamentos podem ser concedidos a emprêsas construtoras ou imobiliárias, incorporadoras de edifícios de apartamentos, condomínios ou condôminos, cooperativas de materiais de construção, adquirentes de casa própria ou os que estejam construindo, bëm como outros produtores ou promotores de habitações.

Nessa modalidade de financiamento, além dos agentes do $\mathrm{SFH}$, o BNH vem utilizando os serviços da rêde bancária particular, por considerar que é do maior interêsse a canalização de recursos para o interior do País como medida capaz de possibilitar a absorção da mão-de-obra ociosa, reduzindo-se, por outro lado, as correntes migratórias para os grandes centros urbanos.

No triênio 1970/1972, o referido Banco deverá aplicar no RECON, 11,9 milhões de UPC, o que permitirá a construção de 42.000 unidades residenciais no valor global de 23,8 milhões de UPC.

b) FINANCIAMENTO E REFINANCIAMENTO DO CAPITAL DE GIRO DO PRODUTOR DE MATERIAIS DE CONSTRUÇÃO (REGIR)

Com o volume de obras previstas no Plano Nacional de Habitação e com o conseqüente aumento do consumo de materiais de construção, as emprêsas produtoras dêsses materiais tiveram que reformular e ampliar suas linhas de produção. Para tanto, havia necessidade de acesso a um tipo especial de crédito que Ihes possibilitasse atingir tal objetivo, o que exigia a utilização integral dos equipamentos existentes, assim como a aquisição de novos equipamentos.

Se tais emprêsas tivessem de recorrer ao crédito bancário comum, que se caracteriza por prazos curtos e juros elevados, os materiais produzidos sofreriam inevitàvelmente as 
conseqüências do alto custo do dinheiro, concorrendo, assim, para onerar os preços finais das habitações.

Para sanar êsse inconveniente, o BNH instituiu o REGIR, através do qual as firmas produtoras contam com uma modalidade de crédito estável, imune às oscilações da conjuntura monetária, a custos reais sensivelmente mais reduzidos, podendo, assim, fornecer os materiais de sua produção em grandes quantidades e a preços acessiveis.

As aplicações no REGIR, no triênio, devem atingir o total de 1,4 milhões de UPC, a que corresponderam investimentos globais superiores a 1,6 milhões de UPC.

\section{c) FINANCIAMENTO E REFINANCIAMENTO DO ATIVO FIXO DAS EMPRESAS (REINVEST)}

Os financiamentos concedidos pelo REINVEST se destinam, de modo especial, à ampliação, racionalização e modernização das firmas produtoras, transportadoras e distribuidoras de materiais de construção. $O$ que se procura com êste Subprograma é aumentar a oferta e, conseqüentemente, reduzir os preços dos produtos.

Para a consecução de tal desiderato, na programação dos seus financiamentos, os agentes financeiros deverão dispensar tratamento prioritário às emprêsas que:

a) se comprometam, de forma expressa, a elevar seus índices de produção e produtividade, além de contribuir para aumento dêsses índices na indústria de construção civil;

b) atendam às peculiaridades regionais e desempenhem atividades de indiscutível importância para o desenvolvimento econômico da área considerada;

c) contribuam para suprir a falta de certos materiais, verificada não só em mercados locais como em outras áreas do País;

d) além de comprovar a existência de mercado para o consumo dos seus produtos, não pertençam ao mesmo grupo econômico que controla o capital do agente financeiro.

Para o atendimento de suas finalidades, o REGIR disporá, no triênio 1970/1972, de 4,1 milhões de UPC, quantia que, somada aos recursos próprios dos agentes e das indústrias, deverá gerar investimentos da ordem de 4,6 milhões de UPC. 
Os técnicos incumbidos de formular a Política Nacional de Habitação não cuidaram apenas dos aspectos puramente habitacionais. Montaram um conjunto de sistemas que abrangem, em têrmos práticos e exeqüiveis, o encaminhamento de solução para numerosos problemas correlatos.

Entre as providências tomadas com essa finalidade, podemos assinalar a criação de várias modalidades de fundos, muitos dos quais, por simples conveniência de melhor ordenação da matéria, serão estudos nos itens relativos a outros sistemas a que estão diretamente associados.

Assim sendo, trataremos aqui sòmente do Fundo de Financiamento de Planos de Desenvolvimento Local Integrado (FIPLAN), do Fundo Especial para o Desenvolvimento do Plano Habitacional do IPASE (FUNDASE), do Fundo de Desenvolvimento Comunitário e do Fundo de Financiamento para Saneamento (FISANE).

a) FUNDO DE FINANCIAMENTO DE PLANOS DE DESENVOLVIMENTO LOCAL INTEGRADO (FIPLAN)

O Decreto no 59.917/66, em seu art. 21, criou o Fundo de Financiamento de Planos de Desenvolvimento Local Integrado (FIPLAN), constituído de recursos postos à sua disposição pelo $\mathrm{BNH}$, de empréstimos ou doações de entidades internacionais ou estrangeiras, de contribuições oriundas de entidades financeiras nacionais e de rendimentos provenientes de suas operações.

"O Planejamento Local Integrado consiste em procurar planejar tôda uma área municipal ou intermunicipal, determinando metas para o desenvolvimento e programas de ação envolvendo todos os aspectos da realidade local. Não sòmente os aspectos físicos devem ser levados em consideração, mas todos aquêles diretamente relacionados com a evolução econômica, de forma que sejam adotadas medidas que fomentem a industrialização, quer através da criação de zonas industriais, quer por meio de iniciativas fiscais que permitam o desenvolvimento da região ou exploração dos seus recursos naturais."

Numerosos outros fatôres são igualmente levados em conta na implantação de um Plano de Desenvolvimento Local Integrado, especialmente no tocante à melhoria das condições

8. Relatório do BNH (1969), pág. 106. 
sociais, mediante a organização de comunidades, de sistemas escolar, hospitalar, recreativo etc.

Cabe ao SERFHAU formular a política nacional de Desenvolvimento Local Integrado, fixando as diretrizes de desenvolvimento regional, em articulação com o Ministério do Interior, que dispõe de um conjunto de órgãos específicos, com larga experiência nesse campo.

Numerosas iniciativas estão em franca execução no que se refere a planos de desenvolvimento local integrado, abrangendo nada menos de 32 municípios, distribuídos por 8 Estados. Os financiamentos são concedidos a grupos de municípios que formem micro-regiões com população igual ou superior a 50.000 habitantes.

\section{b) FUNDO DE FINANCIAMENTO PARA SANEAMENTO (FISANE)}

Com destinação específica para o financiamento de estudos, projetos e obras de saneamento e irrigação, foi instituído, pelo Decreto $n$ ? 61.160/67, um Fundo de Financiamento para Saneamento (FISANE), cujos recursos são formados:

a) por dotações federais, orçamentárias ou extra-orçamentárias, que se destinem a empréstimos para estudos, projetos e obras de saneamento, consignadas ao Ministério do Interior;

b) por recursos provenientes de empréstimos externos, com destinação idêntica à prevista na alínea anterior;

c) contribuições oriundas de empréstimos de agências financeiras da União ou dos Estados;

d) por recursos de outras origens, inclusive rendimentos decorrentes de suas operações, compreendendo reembôlso de capital, juros, comissões etc.

$\mathrm{Na}$ regulamentação do Fundo, levada a efeito pela Portaria $n$ ? 214, de 14 de setembro de 1967, do Sr. Ministro do Interior, foi consideràvelmente ampliada sua área de aplicações. Além de estudos, projetos e obras de saneamento, permitiu-se, também, o financiamento da execução de obras, serviços, prestação de assistência técnica, ampliação e melhoria de sistemas de esgotos sanitários, abastecimento de água em centros populacionais, drenagem, contrôle de inundações e irrigação.

Com o propósito de garantir a boa aplicação dos recursos disponíveis, o Ministério do Interior, em sua portaria já mencio- 
nada, condicionou a aprovação dos contratos de financiamento à satisfação das seguintes exigências:

a) apresentação de relatório técnico preliminar, estudos de viabilidade econômico-financeira e elaboração do projeto técnico do empreendimento a ser financiado;

b) participação do mutuário nas despesas relativas às obras e serviços programados;

c) participação financeira do Estado, quando se tratar da formação de fundo estadual para subempréstimos;

d) adoção de sistemas de tarifas reajustáveis, segundo critérios prèviamente estabelecidos, de forma que fique assegurada a correção suficiente para o reembôlso do financiamento e respectivos juros, taxas, despesas de operação, manutenção e administração do sistema financiado;

e) atualização do valor do empréstimo, mediante correção monetária;

f) rentabilidade superior aos custos financeiros e operacionais dos recursos, bem como existência de órgão autônomo, responsável pela administração, operação e manutenção da obra financiada.

Ao aprovar o programa de financiamento para Saneamento, o BNH, como órgão gestor do Fundo, além de tornar ainda mais explícita a forma operacional do sistema, procurou dar maior amplitude aos recursos do FISANE, permitindo a instituição de Fundos de Água e Esgôto (FAE), regionais, estaduais ou intermunicipais, com a participação financeira obrigatória das entidades que concorrem para a sua criação.

c) FUNDO ESPECIAL PARA O DESENVOLVIMENTO DO PROGRAMA HABITACIONAL DO IPASE (FUNDASE)

A classe dos servidores públicos foi grandemente beneficiada pelo Plano Nacional de Habitação, pois, além de contar com os empréstimos concedidos pela Caixa Econômica Federal e por outras entidades do Sistema Financeiro de Habitação, o Govêrno instituiu junto ao IPASE um Fundo Especial para Desenvolvimento do Programa Habitacional daquela autarquia (FUNDASE), com a exclusiva finalidade de solucionar o problema da moradia dos funcionários públicos federais.

Como parte integrante do patrimônio do IPASE, o FUNDASE é administrado pela Carteira de Aplicação de Capital daquele Instituto. Os recursos do Fundo são aplicados segundo pro- 
gramação estabelecida de comum acôrdo com o $\mathrm{BNH}$, tendo em vista a distribuição geográfica dos servidores, o valor relativo da arrecadação do IPASE nas diferentes regiões e as áreas consideradas prioritárias sob o aspecto social, e são constituídos:

a) de $80 \%$ no mínimo das dotações destinadas, no orçamento geral da autarquia, à execução de programa habitacional, as quais serão automàticamente incorporadas ao Fundo, à medida que a receita comportar;

b) da receita decorrente da amortização e juros de empréstimos imobiliários concedidos pelo IPASE, à conta do Fundo ou com recursos anteriormente utilizados;

c) da receita resultante de operações de refinanciamento realizadas com agências de crédito e financiamento, inclusive com o $\mathrm{BNH}$;

d) da renda de títulos ou depósitos no BNH de disponibilidades que não sejam imediatamente utilizadas;

e) de outros recursos transferidos por entidades públicas ou privadas.

\section{d) FUNDO DE DESENVOLVIMENTO COMUNITARIO}

De acôrdo com a orientação traçada pelo $\mathrm{BNH}$, ao lado dos financiamentos a pessoas físicas e jurídicas para construção e aquisição de unidades residenciais, atenção especial deve ser dada à edificação de conjuntos habitacionais.

As comunidades formadas por tais conjuntos devem ser oferecidas condições de vida e desenvolvimento, expressas em acesso à alimentação, educação, saúde, trabalho e recreação, além do seu relacionamento com outras comunidades, pelas facilidades de transporte, comunicações e intercâmbio econômico e social.

Não raro conjuntos residenciais, construídos em pouco tempo, passam a abrigar dezenas de milhares de pessoas de procedência, costumes, niveis social, intelectual e cultural inteiramente diversos. Em tais aglomerados, conquanto as condições de vida sejam razoàvelmente boas, a heterogeneidade dos seus habitantes dá origem a atritos e desajustamentos de tôda sorte. Cabe, pois, às autoridades responsáveis pela politica nacional de habitação contribuir para que os membros dessas comunidades possam atingir, em sua plenitude, o desenvolvimento de suas potencialidades, a integração no meio em que vivem e o melhor relacionamento possível com seus semelhantes. 
Daí a idéia da constituição de um Fundo por meio do qual possam ser contratados os serviços de instituições especializadas em desenvolvimento de comunidades, as quais, através de diagnósticos e de pesquisas racionalmente dirigidas, tenham condições de indicar as providências que devam ser adotadas visando à perfeita integração dêsses contingentes populacionais.

Êste projeto, não obstante achar-se em fase ainda embrionária, prestará sem dúvida assinalados serviços no melhor entrosamento das comunidades surgidas com o advento dos conjuntos habitacionais financiados pelo $\mathrm{BNH}$.

\section{SISTEMA DE PROJETOS}

O Plano Nacional de Habitação engloba, num conjunto orgânico e harmonioso, uma série de projetos, programas, operações e providências visando a dar solução ao problema habitacional.

Inovação da maior relevância, em matéria de planejamento governamental, consiste na associação de recursos e experiências, oficiais e particulares, orientação que vem produzindo resultados altamente animadores. Não se trata, desta vez, de atuação unilateral do Estado na busca de solução de um problema. Govêrno e iniciativa privada, em perfeito entrosamento, estão realizando um esfôrço combinado, dentro de um objetivo comum e que tem contribuído para tornar o Plano Nacional de Habitação uma realidade palpável e um empreendimento que certamente servirá de modêlo a outros povos que desejem encarar com seriedade a erradicação dos seus deficits habitacionais.

PROJETO-IMPACTO

Exemplo típico dessa nova orientação é o Projeto-Impacto, que tem como dupla finalidade a construção de unidades residenciais em condomínio e o estímulo à iniciativa particular, através da indústria da construção civil.

Mediante o emprêgo de recursos adequados, o BNH promove o apressamento da construção de edifícios residenciais, cujas obras não venham seguindo o ritmo desejado, por insuficiência de disponibilidades financeiras, e permite, por outro lado, o reinício daquelas que se encontrem paralisadas, pelo fato de os adquirentes de apartamentos não disporem de reservas para custear o andamento da construção. 
Esta forma de auxílio financeiro, além de outras vantagens, permite a redução dos prazos de construção, tornando-as mais econômicas, pela ausência de reajustamento e pelo poder de barganha que os incorporadores usam junto aos fornecedores de materiais.

Os financiamentos se destinam a obras que hajam atingido no mínimo $50 \%$ do projeto, ficando desde logo excluídas as de que forem proprietários, promitentes compradores, cessionários ou promitentes cessionários de outro imóvel na mesma localidade. O valor de cada unidade residencial não poderá ultrapassar 400 vêzes o maior salário-mínimo vigente na região.

PROJETO-EMPRESA

Êsse projeto visa a dar apoio financeiro a organizações industriais, comerciais e agrícolas, assim como suas fundações legalmente constituídas, que, em conjunto ou isoladamente, desejem promover a execução de programas de construção de moradias para seus empregados, servidores ou associados. 0 BNH poderá, também, fornecer recursos a emprêsas que se dispuserem a efetuar a venda de habitações já construídas, mediante a aquisição das respectivas hipotecas.

Os conjuntos habitacionais podem ser construídos em terrenos de propriedade da emprêsa ou naqueles que esta adquirir com tal destinação.

Os recursos para execução dêste projeto são constituídos das seguintes contribuições:

a) do BNH ou dos Agentes Financeiros, até $50 \%$ do valor do projeto (esta participação pode ser aumentada para até $75 \%$ nos projetos ou em relação a partes do projeto em que o valor final de venda previsto não exceda de 75 vêzes o maior salário-mínimo fiscal);

b) dos empregados, servidores ou associados, através de poupança prévia ou pagamento inicial efetuado antes ou durante a realização do projeto, até $30 \%$ do valor da unidade habitacional pretendida;

c) da emprêsa, no mínimo de $30 \%$ do valor total do projeto.

A contribuição da emprêsa pode ser representada por terrenos, recursos próprios, empréstimos obtidos fora do SFH, obras de infra-estrutura ou comunitárias, materiais de construção etc. 
No caso de a emprêsa não se achar tècnicamente preparada para elaborar o projeto, esta tarefa poderá ser delegada a organizações especializadas que, com a denominação de administradoras, recolherão todos os elementos indispensáveis à efetivação do empreendimento, tais como levantamento sócioeconômico, projeto, aprovação, construção, venda, escritura, registro, recebimento etc.

As condições gerais dos financiamentos, incluindo prazos, correção monetária, limites e requisitos para o deferimento, reembôlso, e garantias, constam da regulamentação baixada pelo Banco, através da Resolução da Diretoria n: 8/67.

O Projeto-Emprêsa, como se vê, é mais um instrumento que o BNH maneja no sentido de unir esforços e recursos do Govêrno e da área privada com o fim de solucionar o problema da casa própria.

\section{SISTEMA DE GARANTIAS}

Num empreendimento da magnitude do que estamos estudando, em que são movimentados recursos de grande vulto, seria uma insensatez deixar de cercar as aplicações de cautelas especiais, visando a garantir a reversão das quantias emprestadas, pois, do contrário, o Sistema correria o risco de sofrer constantes e insanáveis prejuízos, de conseqüências imprevisiveis para o desenvolvimento das atividades habitacionais.

Cônscio de suas responsabilidades no tocante ao correto e seguro emprêgo dos dinheiros que the foram confiados, 0 $\mathrm{BNH}$ estabeleceu rigoroso esquema de garantias reais, compreendendo duas modalidades de seguro, um fundo de garantia de depósitos e de Letras Imobiliárias, avais, hipotecas, notas promissórias, letras de câmbio, vinculação de receita etc.

Das garantias acima referidas, três assumem posição de maior destaque. Referimo-nos ao Fundo de Garantia de Depósitos e Letras Imobiliárias, ao Seguro Compreensivo e ao Seguro de Crédito Interno, que serão a seguir ligeiramente estudados.

\section{a) FUNDO DE GARANTIA DOS DEPÓSITOS}

E LETRAS IMOBILIARIAS

Uma das principais características do Mercado de Capitais instituído pela Lei $n$ o 4.728 , de 14 de julho de 1965, é a segurança oferecida pelos ativos financeiros postos em circulação. O Govêrno não se limitou apenas a restaurar o conceito dos papéis oficiais, que hoje gozam de ampla aceitação, gra- 
ças à rigorosa pontualidade com que são resgatados; procurou, igualmente, garantir os títulos de emissão de instituições financeiras particulares, para que êstes pudessem desfrutar das necessárias condições de liquidez sem as quais dificilmente seriam negociados.

Com o advento do Plano Nacional de Habitação, e em face da orientação desde logo vitoriosa de se buscarem em áreas privadas os recursos indispensáveis à execução daquele empreendimento, as autoridades governamentais resolveram adotar precauções especiais no uso dos instrumentos de captação de poupanças, não só para manter incólume o prestígio e o bom nome do sistema, mas também para assegurar ao investidor o retôrno das quantias empregadas, nos prazos previstos e com os rendimentos prometidos.

Entre as medidas tomadas pelo $\mathrm{BNH}$, podemos destacar a constituição do Fundo de Garantia dos Depósitos e Letras Imobiliárias, destinado a cobrir financeiramente, na data do seu vencimento, a integridade das poupanças aplicadas em Letras Imobiliárias, Cadernetas de Poupança, Depósito a prazo fixo etc., no caso de insolvência da emprêsa responsável.

A época de sua instituição, o Fundo contava com um capital inicial de um milhão de cruzeiros, integralizado pelo $\mathrm{BNH}$, mais reserva cumulativa proveniente das contribuições pagas pelos Agentes Financeiros sôbre o volume global de suas operações, além da renda decorrente da aplicação dos seus recursos.

A taxa de contribuição para o Fundo foi fixada em $0,125 \%$ por trimestre, aplicável sôbre o saldo total dos depósitos e letras emitidas no último dia do trimestre anterior pelos agentes financeiros ligados ao setor de habilitação.

O Fundo garante as importâncias depositadas em agentes financeiros até o total de 400 UPC por pessoa e as Letras Imobiliárias quando regularmente emitidas.

O Fundo é administrado e fiscalizado pelo $\mathrm{BNH}$, e os seus recursos poderão ser aplicados em suas finalidades precípuas e, ainda, a critério exclusivo da Diretoria do Banco, em:

a) refinanciamento ou suprimentos especiais para cobertura de deficits eventuais de operação;

b) suprimento financeiro, a fim de sanar situações de iminente insolvência;

c) suprimento financeiro nas situações de declarada insolvência. 
b) SEGURO COMPREENSIVO

Esta modalidade de seguro tem por fim garantir a cobertura dos riscos conseqüentes de acontecimentos prèviamente definidos e de ocorrências fortuitas e imprevisíveis.

A operação de seguro é contratada com um Consórcio de Seguradoras composto de emprêsas particulares que assumem, em partes iguais, as responsabilidades previstas na apólice respectiva. Podem igualmente funcionar como seguradoras entidades públicas que operem no ramo de seguros e que aceitem as responsabilidades nas proporções e nas condições que forem estipuladas pelo $\mathrm{BNH}$.

São os seguintes os riscos cobertos, os quais abrangem o imóvel e o seu adquirente:

Quanto ao imóvel:

a) incêndio ocasionado por qualquer causa fortuita;

b) queda de raio;

c) explosão ocorrida dentro da área do terreno onde estiver localizado o imóvel;

d) desmoronamento;

e) terremoto;

f) impacto de veículo terrestre;

g) queda de aeronave;

h) tumulto, motins, inclusive incêndio em conseqüência dêsses eventos.

Quanto ao adquirente:

a) danos materiais diretamente resultantes dos riscos cobertos;

b) danos materiais decorrentes da impossibilidade de remoção ou proteção dos salvados, por motivo de fôrça maior;

c) danos materiais e despesas decorrentes de providências tomadas para combate à propagação dos riscos cobertos, para salvamento e proteção dos bens descritos na Apólice e desentulho do local.

c) SEGURO DE CRÉDITO INTERNO

O Seguro de Crédito Interno tem em vista cobrir os riscos e garantir a liquidez dos financiamentos realizados pelas entidades vinculadas ao SFH, exceto as Companhias Habitacionais de natureza estatal, assim como as operações efetuadas 
por estabelecimentos bancários, quando devidamente credenciados como agentes financeiros do $\mathrm{BNH}$.

O seguro protege apenas as unidades residenciais que objetivem a erradicação de aglomerado de habitações antihigiênicas ou, a critério do órgão financiador, as que se destinem a classes de baixa renda.

$\mathrm{Na}$ forma das condições gerais descritas na Apólice, "ficam seguradas as perdas líquidas definitivas ocorridas nos financiamentos pelo segurado, em virtude de insolvência ou incapacidade de pagamento, mesmo quando decorrentes de êrro ou omissão, contrafação, adulteração, fraude ou falsificação praticadas pelo financiado ou terceiros em/ou de documentos exigiveis para os contratos de quaisquer operações de crédito, sempre que as datas de realização efetiva dêsses financiamentos estejam compreendidas dentro do período de vigência da apólice e que suas datas sejam anteriores à insolvência dos financiados".

É igualmente facultada a cobertura dos riscos decorrentes de todos os financiamentos que, embora efetivados em data anterior à do início da vigência da Apólice, preencham os requisitos da legislação e normas regulamentares aplicáveis à espécie, em vigor na data de sua contratação e não apresentem qualquer inadimplência pelos financiados.

\section{d) OUTRAS FORMAS DE GARANTIAS}

Nos financiamentos ou refinanciamentos realizados pelo $\mathrm{BNH}$, salvo os efetuados com seus agentes financeiros, além de outras garantias reais, exige-se mais uma das seguintes:

a) fiança bancária;

b) hipoteca de bens imóveis não residenciais;

c) caução de crédito não originado na operação;

d) fiança de govêrno estadual ou municipal com vinculação de receita.

É obrigatório o seguro de vida temporário em quaisquer contratos de venda ou construção de habitação com pagamento a prazo, cujo valor exceder do maior salário-mínimo vigente no País.

\section{SISTEMA DE CORREÇÃO DAS APLICAÇÕES}

a) CORREÇÃO MONETARIA

Como todos se recordam, ao assumir a Presidência da República, em abril de 1964, o saudoso Marechal Humberto de 
Alencar Castelo Branco, contrariando poderosas correntes de opinião, determinou a adoção de uma política gradualista de combate ao surto inflacionário que dominava o País.

Em virtude da orientação firmada por aquêle eminente estadista, a inflação não seria submetida a tratamento de choque, o que poderia ocasionar uma recessão econômica de conseqüências imprevisíveis. O flagelo seria atacado em suas origens e posto sob contrôle, de modo que as taxas inflacionárias fôssem sendo gradativamente reduzidas, até que se contivessem em limites suportáveis, na hipótese de não se conseguir sua completa extinção.

Ao planejar sua política habitacional, o Govêrno estava. pois, diante de uma situação dificilmente contornável. O emprêgo de dotações orçamentárias, como vimos, fôra desde logo recusado e o apêlo à poupança privada não encontraria maior ressonância, pois nenhuma pessoa de bom senso cometeria o desatino de entregar suas economias a determinada instituição para, depois de algum tempo, recebê-las de volta com seu poder aquisitivo completamente deteriorado.

Uma equipe de técnicos foi convocada para solucionar o problema e, após estudá-lo, convenientemente, encontrou uma fórmula verdadeiramente notável, pois conseguiu compatibilizar os investimentos a longo prazo com a conjuntura inflacionária. Trata-se da chamada correção monetária, que passou a ser utilizada não apenas pelos Agentes do Sistema Financeiro de Habitação, nos empréstimos que concedem para construção ou aquisição de casa própria, mas especialmente como forma de garantir ao investidor a integridade de suas poupanças e o recebimento de remuneração compensadora dos capitais empatados.

Graças à adoção dessa providência, o Banco Nacional de Habitação pôde angariar os fabulosos recursos com que vem financiando a construção de centenas de milhares de unidades residenciais.

b) FUNDO DE COMPENSAÇÃO DE VARIAÇÕES SALARIAIS (FCVS)

Mas, a aplicação da correção monetária aos financiamentos para aquisição ou construção de casa própria criou, para os mutuários e para os próprios órgãos do Sistema, algumas dificuldades que precisavam ser afastadas o quanto antes.

Os desajustes financeiros ocasionados pela forma de incidência da correção colocavam os adquirentes de imóveis em 
situação de incerteza quanto aos prazos e ao número de prestações necessárias à liquidação do seu débito.

O assunto se reveste de certa complexidade e será melhor estudado quando tratarmos do Plano de Equivalência Salarial. Por enquanto, limitar-nos-emos a comentar a solução que o $\mathrm{BNH}$ inicialmente encontrou para enfrentar os óbices resultantes da defasagem financeira entre os reajustamentos das prestações de amortização, que decorrem da alteração dos níveis do saláriomínimo, e os aplicados trimestralmente ao saldo devedor, com base nas oscilações do valor das Obrigações Reajustáveis do Tesouro Nacional (ORTN).

Para impedir que as divergências entre os dois tipos de reajustamento acarretassem o prolongamento indefinido da dívida, colocando os compradores em situação de insegurança e ansiedade, o BNH baixou normas estabelecendo que as mensalidades adicionais necessárias à liquidação do débito não poderiam, em qualquer hipótese, ultrapassar a $50 \%$ do prazo inicialmente fixado. Quando a dívida excedesse de tal prazo, as prestações restantes seriam pagas pelo Banco.

Aquela autarquia não dispunha, porém, de recursos para fazer face a despesas tão elevadas. Precisava, por conseguinte, recorrer a alguma fonte através da qual pudesse solver tais compromissos. Foi, assim, criado o Fundo de Compensação de Variações Salariais (FCVS), com recursos provenientes de:

a) capital inicial de $\mathrm{Cr} \$ 10.000,00$;

b) taxa correspondente a uma prestação de amortização e juros da dívida garantida, paga pelo adquirente no ato de inscrição no Fundo;

c) rendimento líquido dos seus recursos e operações.

As entidades do SFH que se utilizarem do Fundo serão obrigadas a fazê-lo em todos os seus contratos, podendo entretanto dêle se retirar, desde que o façam em caráter definitivo e abram mão das contribuições anteriormente pagas.

O sistema operacional do Fundo, nos têrmos das disposições constantes dos atos que o instituíram e regulamentaram, era bastante simples. Para as operações incluídas nos Planos "A" e "C", findo o prazo previsto no contrato, far-se-ia a apuração do saldo devedor ou credor, porventura existente. No caso de saldo credor, êste seria devolvido ao financiado, acrescido dos juros e correção monetária a que tivesse direito. Se o saldo fôsse devedor, o adquirente prosseguiria na amortização do débito até atingir $50 \%$ das prestações previstas no contrato inicial. A parte restante seria liquidada pelo FCVS. 
Esta iniciativa, como se verificará mais adiante, não resolveu totalmente a questão em virtude da interferência de outros fatôres, motivo por que o BNH teve que lançar o Plano de Equivalência Salarial, instrumento sem dúvida da maior importância e que veio, ao que tudo indica, pôr fim às distorções ocorridas no Sistema, em virtude da aplicação da correção monetária.

\section{c) PLANO DE EQUIVALENCIA SALARIAL (PES)}

O Plano de Equivalência Salarial surgiu com a finalidade de complementar o Fundo de Compensação de Variações Salariais em seu objetivo de eliminar os transtornos verificados na aplicação da correção monetária aos financiamentos concedidos nas faixas abrangidas pelos Planos " $A$ " $e$ " $C$ ".

Para que o leitor possa melhor compreender o assunto, descreveremos as principais características dos planos acima mencionados.

No Plano " $A$ ", as prestações mensais de amortização e juros dos empréstimos para aquisição de casa própria sofriam reajustamentos anuais, tôda vez que se elevava o salário-mínimo, no caso de empregados sujeitos à CLT, ou quando se aumentavam os vencimentos, na hipótese de se tratar de funcionário público. A nova prestação, devidamente corrigida, entrava em vigor 60 dias após a concessão dos benefícios, sendo o seu valor fixado proporcionalmente ao acréscimo atribuído ao maior salário-mínimo vigente no País.

No Plano "C", a situação era mais ou menos semelhante, com a diferença de que a nova prestação passava a vigorar no mês seguinte ao do dissídio coletivo ou do acôrdo salarial da categoria profissional, e não 60 dias depois da decretação do nôvo salário-mínimo.

Em ambos os casos, porém, não apenas as prestações de amortização eram reajustadas. Corrigia-se também, monetàriamente, o saldo devedor com o escopo de compensar a perda do poder aquisitivo da moeda e conciliá-lo com as diversas variáveis do problema.

Mas, enquanto o reajustamento das prestações de amortização e juros se fazia uma vez por ano, na mesma proporção do aumento verificado no salário-mínimo, o saldo devedor era reajustado trimestralmente, com base nas variações ocorridas nas Obrigações Reajustáveis do Tesouro Nacional (ORTN) e determinadas pelos índices de preços por atacado da Fundação Getúlio Vargas. 
Essa diferença de critérios deu origem a um descompasso financeiro, com graves reflexos sôbre o Sistema.

Quando examinamos o FCVS, frisamos que, com o fim de remover as dificuldades surgidas e tranqüilizar os adquirentes de casa própria, o BNH fixou em $50 \%$ o número de prestações excedentes das estabelecidas no contrato inicial. As que ultrapassassem êsse limite seriam liquidadas através do referido Fundo.

Mas, com esta providência não se deu solução definitiva ao problema, pois outros fatôres se incumbiram de introduzir no Sistema novos elementos de perturbação. A data do pagamento das prestações, por exemplo, exercia grande influência na fixação de maior ou menor prazo para o resgate da dívida, uma vez que "os empréstimos concedidos imediatamente antes do advento de nôvo salário-mínimo tinham as prestações logo a seguir reajustadas, enquanto os empréstimos concedidos imediatamente depois dêsse mesmo salário-mínimo sòmente seriam reajustados após a superveniência de novos níveis salariais".?

Embora aparentemente tal fato não se revestisse de maior significação, na prática havia uma diferença fundamental quanto ao pagamento da divida. No primeiro caso, a liquidação do débito tendia a verificar-se antes do prazo estipulado no contrato, ao passo que, no segundo, a tendência era prolongar-se além dos limites inicialmente fixados.

A matéria é muito interessante e está sendo aqui exposta de forma sumária. Quem desejar obter maiores detalhes poderá encontrá-los no magnífico trabalho de Oswaldo lório, já citado, cuja leitura temos a satisfação de recomendar.

Com a instituição do Plano de Equivalência Salarial, o problema foi satisfatòriamente solucionado de vez que, mantido o esquema de reajustamentos constantes dos Planos " $A$ " e " $C$ ", o número de prestações contratadas será fixo, exceto na hipótese bastante remota de liquidação antecipada ou amortização extraordinária da dívida. Assim sendo, o mutuário que contrair um empréstimo, desde que não fuja às suas obrigações contratuais, fará sua liquidação no prazo fixado, sem qualquer prorrogação.

Também no que se refere ao saldo devedor, o PES introduziu salutar inovação. No sistema anterior (Planos " $A$ " e "C"), o referido saldo era corrigido, monetàriamente, quatro vêzes ao ano. Pelo PES, tal compromisso é assumido, em nome do mu-

9. Oswaldo Iório - "O Que é o Plano de Equivalência Salarial?" Editado pela Secretaria de Divulgação do $\mathrm{BNH}$, pág. 5 . 
tuário, pelo Fundo de Compensação de Variações Salariais. O adquirente de imóvel fica, pois, livre da preocupação que antes para êle representava a evolução do saldo devedor do seu empréstimo, pois, como ressalta Oswaldo lório, "ao final do prazo convencionado, o seu débito, ou estará reduzido a zero, ou representado por um valor qualquer e, nesse caso, será liquidado pelo FCVS. O compromisso do financiado é pagar o número de prestações estabelecidas no contrato, no valor préfixado, em função do maior salário-mínimo vigente no País. Se - FCVS responde ou não pela liquidação dos saldos remanescentes a circunstância em nada afeta ao mutuário, já que os acertos de contas, nesse particular, serão feitos entre o BNH e os agentes financeiros do sistema".

Outra modificação de grande efeito prático foi o critério adotado na fixação da prestação inicial, cujo valor resulta da multiplicação da mesma por uma constante denominada coeficiente de equiparação salarial a ser determinada, periòdicamente, com validade para cada um dos trimestres civis do ano. Com tal medida, as possíveis divergências entre a evolução dos níveis de preços e a dos níveis do salário-mínimo não mais ocasionarão as defasagens financeiras cujos inconvenientes tivemos ocasião de salientar.

\section{SISTEMA DE APOIO TÉCNICO}

Já vimos que o Plano Nacional de Habitação constitui um sistema de sistemas diretamente correlacionados com as demais áreas da economia.

Para dar cobertura à execução de tão arrojado empreendimento, o Govêrno teria que montar um perfeito esquema de apoio técnico, capaz de fornecer a cada órgão engajado no processo os elementos de que porventura necessite para o pleno e eficiente desempenho de suas funções.

Partindo dêsse pressuposto, e antevendo o impacto que as maciças aplicações do Sistema iriam ocasionar em tôda a economia brasileira, notadamente em nossa estrutura técnico-industrial, o BNH está realizando numerosos estudos, pesquisas, levantamentos, treinamento de pessoal e outras atividades de apoio técnico ao plano habitacional, em consonância com as diretrizes básicas consubstanciadas em rigorosa programação.

Por intermédio de sua Assessoria de Planejamento e Coordenação, o citado órgão centraliza as tarefas normativas, de orientação e contrôle, delegando a execução das providências 
planejadas a diversas instituições, vinculadas ou não àquela autarquia.

Sempre que possível, aproveita-se a experiência de organismos públicos ou privados, que já venham realizando atividades em áreas de interêsse para o Banco. Neste caso, a Assessoria procura ordenar, sistematizar, analisar e desenvolver tais atividades, orientando-as no sentido do atendimento das necessidades fundamentais do setor. $\mathrm{Na}$ maioria dos casos, porém, os trabalhos são levados a efeito por meio de convênios com outras instituições especializadas, hipótese em que o Banco não apenas se incumbe de fornecer orientação, mas também financia a execução das tarefas.

Em 1969, foi elaborado um plano para ser implantado a partir do corrente ano, reunindo diversas medidas de apoio técnico, com a exata definição dos seus objetivos, prioridades, órgãos executores, inter-relações dos diferentes órgãos, projetos específicos com as respectivas dotações etc. Por meio dêsse plano, procurou-se unificar e coordenar num só programa as iniciativas que antes estavam sendo conduzidas de forma dispersa, visando a conseguir o máximo rendimento no apoio ao plano habitacional, especialmente com relação à pesquisa e à prestação de assistência técnica.

Em linhas gerais, são as seguintes as principais realizações nesse importante setor:

a) CENTRO NACIONAL DE PESQUISAS HABITACIONAIS (CENPHA)

É uma entidade técnico-científica criada através de convênio entre o Banco Nacional de Habitação e a Pontifícia Universidade Católica do Rio de Janeiro (PUC), sem fins lucrativos e com o objetivo de:

a) promover pesquisas e estudos sôbre o problema habitacional, levando em conta o planejamento físico-técnico, sócio-econômico e jurídico-administrativo de suas relações;

b) promover pesquisas sôbre a construção habitacional e os materiais nela empregados, seu aperfeiçoamento e padronização;

d) realizar pesquisas sôbre a indústria de construção, visando a fomentar seu desenvolvimento e prestar aos interessados a indispensável assistência técnica;

d) promover o treinamento de técnicos em assuntos relacionados com habitação; 
e) manter intercâmbio com entidades congêneres, nacionais ou estrangeiras.

O CENPHA é uma das peças básicas do sistema de apoio técnico, de vez que funciona como núcleo centralizador da coordenação e avaliação das pesquisas e levantamentos de dados para apoio logístico ao Plano Nacional de Habitação.

Entre os principais trabalhos que vem realizando, destacam-se os seguintes:

a) pesquisa pioneira, por amostragem, sôbre o dimensionamento das possibilidades de poupança, por faixa de renda e tamanho de família, com o fim de determinar, quantitativa e qualitativamente, a demanda de habitação da cidade de Goiânia;

b) estudo sôbre a evolução dos aluguéis no Estado da Guanabara, no período de 1966 a 1969;

c) pesquisa sôbre o custo operacional do Sistema Financeiro de Habitação;

d) pesquisa do mercado habitacional da Gamboa, no Estado da Guanabara;

e) avaliação dos projetos da Cidade de Deus e Cidade Alta, também na Guanabara;

f) pesquisa-pilôto do impacto de área de desenvolvimento urbano.

b) CENTRO BRASILEIRO DE CONSTRUÇAO (CBC)

O Centro Brasileiro de Construção ( $C B C$ ), inspirado nos "Bouwcentrum" surgidos na Europa, após a Segunda Guerra Mundial, foi organizado em São Paulo, com a colaboração do $\mathrm{BNH}$, do Centro das Indústrias daquele Estado, do Instituto de Engenharia e do Instituto de Arquitetos, com as seguintes finalidades:

a) estimular o aprimoramento da Indústria de Materiais de Construção;

b) incentivar o aperfeiçoamento da mão-de-obra e a difusão de conhecimentos técnicos e profissionais, relacionados com a construção;

c) organizar exposições permanentes de materiais de construção;

d) testar todos os materiais existentes no mercado, bem como os que forem sendo lançados à venda; 
e) realizar, encaminhar e estimular investigações e pesquisas objetivando abolir, na medida do possível, o amadorismo que ainda existe nos meios ligados à produção de materiais de construção.

A colaboração do $C B C$ na execução do Plano Nacional de Habitação é considerada de importância fundamental. Mediante estudos e testes de laboratório, seus engenheiros e arquitetos procuram padronizar e especificar os materiais de construção, concorrendo, assim, para a melhoria de sua qualidade, quanto à facilidade de uso e duração. Além disso, o estabelecimento de normas, padrões e especificações permitirá que êsses materiais sejam produzidos em massa, a preços sensivelmente reduzidos.

O CBC é mantido com recursos do $\mathrm{BNH}$, contribuições dos seus associados, doações, subvenções e financiamentos. Entre suas atividades, inclui-se a realização de numerosos cursos especializados, em colaboração com o CENPHA, tais como Curso de Industrialização da Construção e Pré-Fabricação, Pert/Tempo/Custo aplicado à Construção e Meio Ambiente, Uso dos Plásticos na Construção, etc.

c) CENTRO DE COORDENAÇÃO INDUSTRIAL
PARA O PLANO HABITACIONAL (CIPHAB)

Os CIPHABs são núcleos de estudos e pesquisas criados pelo $\mathrm{BNH}$, através de convênios com Federações das Indústrias.

A finalidade dêsses centros é promover o racional aproveitamento ou aumento da capacidade de produção da indústria de materiais e equipamentos de construção, com melhoria da qualidade, aumento da quantidade e redução dos custos dos produtos.

Vários trabalhos nesse sentido estão sendo executados pelos CIPHABs do Rio Grande do Sul, São Paulo e Guanabara, mencionando-se entre os mais importantes:

a) coordenação modular;

b) nova política de transportes aplicável ao plano habitacional;

c) estudo de técnicas de construção em uso;

d) estudo básico de sistema de registro e qualificação de emprêsas construtoras;

e) pesquisa sôbre as indústrias de materiais de construção e da construção civil do Paraná; 
f) levantamento cadastral das indústrias de materiais de construção na Guanabara e no Estado do Rio de Janeiro;

g) assistência técnica às indústrias de materiais de construção;

h) diagnóstico da indústria de construção habitacional na Guanabara.

Para se ter uma idéia do valor dos trabalhos realizados pelos CIPHABs, basta acentuar que alguns dêles permitiram não só a atualização ou revisão de critérios e normas operacionais dos financiamentos, como também concorreram para o aprimoramento de todo o Sistema.

\section{d) CENTRO DE INFORMAÇÕES PARA O DESENVOLVIMENTO LOCAL INTEGRADO (CIDUL)}

Em oủtro local dêste relato, tivemos a oportunidade de verificar que o Planejamento Local Integrado consiste na definição das metas e programas colimando o desenvolvimento global de determinada área municipal ou intermunicipal. $\mathrm{Na}$ elaboração do Plano, não sòmente os aspectos físicos devem ser levados em conta, mas todos aquêles relacionados com a evolução econômica, "de forma que sejam adotadas medidas que fomentem a industrialização, quer através da criação de zonas industriais, quer por meio de iniciativas fiscais que permitam o desenvolvimento da região ou a exploração dos seus recursos naturais".

Para a efetivação de um planejamento dessa natureza, cujo grau de complexidade é desnecessário encarecer, os órgãos responsáveis precisam dispor de um acervo de dados e informações que os tornem em condições de confeccionar um documento em que todos aspectos da realidade local sejam devidamente considerados e inter-relacionados.

Êste é o papel que o CIDUL - Centro de Informações para - Desenvolvimento Local - deve desempenhar. Com a criação dêsse órgão, pretende-se montar um verdadeiro banco de dados e informações, em todos os níveis, os quais servirão de base à elaboração de Planos de Desenvolvimento Local Integrado.

\section{e) FORMAÇAOO E TREINAMENTO DE PESSOAL}

Os estudiosos da Administração são unânimes em pôr em relêvo a importância do fator humano em qualquer emprêsa, pública ou privada. 
Leonard D. White, por exemplo, acha que "muitos elementos se associam para formar uma boa administração: liderança, organização, finanças, moral, métodos e normas de trabalho, porém o mais importante de todos é o elemento humano". 10

De fato, o homem é o fator decisivo e dominante, pois sem seu auxílio nada se poderá realizar. "Êle é o cérebro, é a alma, é o braço; é tudo em qualquer esfôrço de realização".

Notadamente num país como o nosso, em que o sistema de ensino se ressente de notórias deficiências estruturais e funcionais, os responsáveis por qualquer empreendimento de grande porte têm que dispensar cuidados especiais ao recrutamento e treinamento dos seus colaboradores dos diferentes níveis hierárquicos. E no caso do Plano Nacional de Habitação as necessidades de pessoal qualificado não afetam apenas os órgãos integrantes do Sistema Financeiro, mas igualmente os demais setores de trabalho, inclusive o relativo à execução de obras. A preparação de mão-de-obra especializada não poderia deixar de ser motivo de preocupação para as autoridades habitacionais.

Sempre atento a tôdas as particularidades do problema, o BNH celebrou convênio com várias entidades para a realização de uma série de cursos de formação e especialização, inclusive por correspondência, destacando-se entre êles:

a) Curso de Política e Integração Habitacional;

b) Curso para Dirigentes de Cooperativas Habitaçionais;

c) Curso de Legislação Imobiliária;

d) Curso de Formação de Corretores de Imóveis;

e) Curso de Contrôle de Execução de Projetos Habitacionais;

f) Curso de Formação de Mestres de Obra;

g) Curso de Alfabetização e Treinamento de Mão-de-Obra não especializada.

f) ANALISE E PESQUISA DE INSUMOS

Sôbre êste assunto pouco teremos a dizer, pois já o fizemos quando tratamos da contribuição dos CIPHABs e do CBC para o aproveitamento de materiais e equipamentos de construção, com aperfeiçoamento da qualidade e redução dos preços dos produtos.

10. Leonard D. White - "Introduction to the Study of Public Administration" - The MacMillan Company - New York - 1940 - pág. 277. 
Os trabalhos nesse campo abarcam uma grande variedade de programas, cujos resultados são sem dúvida satisfatórios, como se poderá constatar pelo grande número de pesquisas e levantamentos feitos pelos CIPHABs de São Paulo, Rio Grande do Sul e Guanabara.

\section{g) SISTEMA OPERACIONAL, DE ANÁLISE E CONTRÔLE}

Neste item incluem-se várias modalidades de estudos e pesquisas, como, por exemplo, levantamento e contrôle de custos; apoio aos censos habitacional, de população e desenvolvimento urbano; pesquisas de mercado; pesquisas de aluguéis e muitas outras, trabalhos que se acham sob a responsabilidade de instituições especialmente constituídas para êsse fim e já mencionadas em outros tópicos.

h) PROJETO ORAC

Em 1969, o Banco Nacional de Habitação celebrou convênio com a Organização das Nações Unidas (ONU) visando à adoção através de uma equipe de alto nível a ser cuidadosamente selecionada, de métodos e processos científicos que orientem as decisões do Banco nos campos administrativo, econômico e social, mediante a institucionalização de eficiente sistema de pesquisas operacionais.

Numa inequívoca demonstração de confiança na capacidade e inteireza dos nossos técnicos, a ONU confiou, em caráter excepcional, a direção do projeto ao próprio órgão assistido, ou seja, ao BNH. Criou-se, então, naquela autarquia, um Grupo de Pesquisa Operacional que, com a colaboração de especialistas brasileiros e estrangeiros, êstes cedidos pelo "Stanford Research Institute", se incumbirá de realizar os trabalhos previstos no programa.

A primeira tarefa objetiva em execução pelo Grupo é o planejamento plurianual das aplicações do BNH. "Esse projeto envolve modelos matemáticos compatibilizando as aplicações com o mercado e as disponibilidades materiais, a nível de localização, os recursos do sistema e o equilibrio com as demais áreas de economia do País".

O Grupo de Pesquisa Operacional vem equacionando os problemas de sua alçada e pretende solucioná-los através do Método de Programação Linear, com o emprêgo de computadores de $3^{\text {a }}$ geração (IBM/360). Utilizará dados do Censo de 1970 e de pesquisas específicas realizadas pelo CENPHA 
(Centro Nacional de Pesquisas Habitacionais), com o fim de planejar as aplicações de modo que atinjam efeitos sociais globais.

CONCLUSÕES

Pela descrição sucinta de suas características fundamentais, já sabemos em que consiste o Plano Nacional de Habitação. Vamos agora apresentar ao leitor uma síntese do que - Govêrno realizou de 1964 a 1969, bem como o que tenciona levar a efeito no período de 1970 a 1972, através dêsse extraordinário empreendimento, que já se firmou no concenso geral como eficaz instrumento de ampliação da saúde do homem e como poderoso fator de desenvolvimento sem inflação.

Antes, porém, desejamos tecer algumas considerações com o fim de ressaltar que, não fôra a utilização de uma estratégia indireta, com imediata repercussão em todos os setores ligados ao problema, certamente as autoridades habitacionais não teriam logrado obter tão brilhantes resultados.

A confiança na iniciativa governamental ensejou o rápido estabelecimento do hábito de poupança, inclusive em áreas antes infensas a êsse tipo de formação de economias, o que possibilitou a mobilização de recursos consideráveis, cuja capitalização a uma taxa média de $7 \%$ ao ano permitirá a duplicação dos mesmos "cada 10.16 anos, a uma velocidade de 2.3 vêzes superior à taxa de crescimento da população e cêrca de 1.3 vêzes superior à taxa de urbanização da população brasileira".

Estes fatos se revestem de particular significação, pois nos levam a concluir que embora a curto prazo as aplicações do $\mathrm{BNH}$ ainda fiquem muito aquém da demanda efetiva de habitação, a médio e a longo prazo, conseguiremos pleno êxito na luta pela total erradicação dos nossos deficits habitacionais.

É bom lembrar que o problema está sendo atacado em seus múltiplos aspectos, por meio de providências que compreendem a construção e reforma de casas; a instalação de rêdes de água e esgôto; o aumento da renda familiar, quer como resultado dos investimentos e dos empregos por êles gerados, quer pelo adestramento do trabalhador; o aumento da capacidade de poupança de nossa população; a redução dos custos dos terrenos urbanizados; o aperfeiçoamento dos mecanismos de captação de recursos; e, finalmente, a redução dos custos finais dos abrigos construídos.

Os itens acima indicados traduzem, em seu perfeito correlacionamento, dois propósitos fundamentais: a melhoria de 
nossas condições econômicas e a redução dos custos finais das unidades residenciais, fazendo-se com que desapareça o descompasso entre os preços das habitações e os níveis de renda familiar.

"Na medida em que se reduza êsse hiato e mecanismos adequados de financiamento ponham a habitação (prestação mensal resultante de prazo, de taxa de juros, poupança prévia e correção monetária) ao alcance da capacidade de pagamento da família, teremos alcançado o objetivo de transformar êsse mecanismo de um mecanismo auto-excitado em um processo auto-sustentado."11

Esta meta vem sendo progressivamente atingida e, em conseqüência, o Banco Nacional de Habitação, nos seus primeiros cinco anos de funcionamento, já pode oferecer apreciável soma de realizações no campo habitacional, com reflexos revitalizadores em vários setores da economia e - o que é mais importante - sem produzir abalos de índole inflacionária.

De 1964 a 1969, as aplicações do Sistema deram origem a investimentos superiores a 13,5 bilhões de cruzeiros. $O$ número de moradias contratadas ultrapassou a 607.000 , tendo sido financiadas, até 31-12-1969, cêrca de 559 mil unidades. Isto significa que, nos seus primeiros anos de existência, o BNH já propiciou abrigo a mais de meio milhão de famílias brasileiras, distribuídas por 399 municípios, com uma área construída superior a 37 milhões de metros quadrados.

Parcela substancial dêsses investimentos resultou da mobilização de poupanças de mais de um milhão e cem mil investidores, captadas através de cadernetas de poupanças e da venda de Letras Imobiliárias, recursos que foram desviados do consumo supérfluo para o investimento e, portanto, para o incremento do nosso progresso econômico e social.

No período de 1970/1972, a ação do Govêrno se fará sentir com mais intensidade, graças ao maior volume de recursos disponíveis, a experiência acumulada ao longo de um qüinqüênio, a redução dos custos operacionais do Sistema, a baixa dos preços dos materiais de construção e dos custos reais das vendas.

No triênio em estudo, por intermédio dos vários programas habitacionais, está previsto o financiamento de mais de 615.000 unidades residenciais, no valor de 12,9 bilhões de cruzeiros.

Relativamente aos programas complementares, os resultados falam igualmente por si mesmos.

11. Dr. Mário Trindade - Obra citada, pág. 21. 
O financiamento de serviços de água, iniciado em 1968, já inclui 956 municípios, 210 dos quais com obras iniciadas, 63 com projetos em exame, $400 \mathrm{com}$ projetos em elaboração e 0 restante em estudos de viabilidade.

Depois de concluída esta etapa, os sistemas instalados terão capacidade para abastecer 51 milhões de habitantes. Se nào houver descontinuidade na execução do programa, em 1980 , calcula-se que teremos $80 \%$ da população brasileira completamente servida de água potável.

Quanto ao Subprograma de esgotos sanitários, ainda é cedo para fazer-se um balanço dos seus resultados. Muita coisa, porém, já se conseguiu nesse campo e numerosas iniciativas estão programadas. Como dados concretos, e não obstante o Subprograma ter surgido em 1969, além do início da construção de sistemas de esgotos em alguns municípios, cuida-se no momento do contrôle da poluição das bacias dos Rios Tietê, Tamanduateí, Piracicaba e Alto Paraíba, no Estado de São Paulo.

Com o desenvolvimento do Subprograma, mediante a instituição de Fundos de Água e Esgotos (FAE), com a participação dos Estados e municípios, a atuação do Govêrno será consideràvelmente ampliada nos próximos anos.

No que tange ao FIMACO, os trabalhos até agora realizados têm produzido efeitos bastante compensadores, conforme tivemos o ensejo de frisar quando do estudo dêste Programa e respectivos Subprogramas. Podemos acrescentar, para melhor informação do leitor, que, em virtude das inversões feitas nas indústrias de construção civil e de produção e distribuição de materiais de construção, já foram obtidos numerosos benefícios, tais como:

a) produção de grandes quantidades de materiais, de qualidade sempre melhor e por preços razoàvelmente mais baixos;

b) redução dos preços dos aluguéis, comprovada em pesquisas feitas por instituições especializadas no assunto;

c) redução dos índices dos preços das construções, que hoje se situam em niveis perfeitamente aceitáveis;

d) manutenção de altos índices de oferta de emprêgo. (Segundo estudo incompleto do Departamento Nacional de Mão-de-Obra, a oferta de novos empregos alcançou, em 1968, 585.467 e, em onze meses de 1969, 569.307);

e) adestramento de 10.000 trabalhadores nos canteiros de obras. (Em 1970, o programa prevê o treinamento de 30.000 empregados não especializados, número que 
aumentará, gradativamente, até atingir 100.000 trabaIhadores por ano);

f) ampliação dos recursos da poupança livre, do Sistema Brasileiro de Poupança e Empréstimo, os quais alcançaram, em 31 de maio do corrente ano, a elevada soma de $\operatorname{Cr} \$ 2.600 .000 .000$ de depósitos, contra .......... Cr\$1.091.966.000 em 31 de dezembro de 1968;

g) expansão do programa de edificação de casas fora do Plano Nacional de Habitação, estimando-se em 100.000 o número de unidades a serem construídas em cada ano;

h) intensificação das atividades habitacionais nas áreas rurais.

Com referência ao Programa de Apoio Técnico, cremos que já foi suficientemente explanado no capítulo anterior, motivo por que nos parece desnecessário repetir os dados que então apresentamos.

Em nossas considerações finais, voltamos a ressaltar que - Plano Nacional de Habitação, verdadeiro sistema de sistemas, obedeceu a um planejamento global e constitui um todo orgânico, em que as diferentes partes estão simètricamente dispostas e harmônicamente interligadas. Graças à maneira revolucionária com que foi concebido e formulado, êste gigantesco empreendimento configura hoje uma das principais realizações em nosso panorama administrativo e já vem produzindo frutos altamente promissores, os quais ainda mais se realçam se levarmos em conta a situação excepcionalmente difícil que o País atravessava quando foram deflagradas as ações nêle previstas.

Dada a complexidade e a amplitude da matéria, e tendo em vista a exigüidade do espaço que nos foi reservado, tivemos que dispensar aos diversos tópicos tratamento rigorosamente sumário. Se a preocupação de síntese prejudicou a clareza e a melhor exposição do assunto, os leitores certamente relevarão esta falta involuntária.

De uma coisa estamos absolutamente certos: iniciativas como a consubstanciada na reforma habitacional precisam ser conhecidas por tôda a população. Elas contribuem para que acreditemos mais em nós mesmos, em nosso talento criador $e$ realizador, em nossa capacidade de solucionar os nossos problemas, por nossos próprios meios, com os nossos próprios recursos e mediante o emprêgo de soluções tìpicamente brasileiras. 